\title{
Morphology Changes at the Nanakita River Mouth after The Great
}

\section{East Japan Tsunami of 2011}

\author{
HITOSHI TANAKA
}

Department of Civil Engineering, Tohoku University, 6-6-06 Aoba, Sendai 980-8579, JAPAN

MOHAMMAD BAGUS ADITYAWAN*

Water Resources Engineering Research Group, Institut Teknologi Bandung, Jalan Ganesha 10, INDONESIA

*Department of Civil Engineering, Tohoku University, 6-6-06 Aoba, Sendai 980-8579, JAPAN.

\author{
AKIRA MANO \\ International Research Institute of Disaster Science, Tohoku University, 6-6-06 Aoba, Sendai \\ 980-8579, JAPAN
}

\begin{abstract}
This study investigates the morphology changes near the Nanakita river mouth in Japan. The morphology of the river mouth was greatly influenced during The Great East Japan Tsunami of 2011. The gradual morphological changes at the river mouth was investigated using two sets of data, o which, one was the continuous water level measurement data in the river entrance and in the sea, and the other being the intermittent aerial-photographs. The statistical parameters, viz., the correlation coefficient and the linear gradient between the two water level data were analyzed, which formed as the basic for understanding the behavior of the river mouth, like river mouth closure or opening detected by the analysis of the water level variation. The proposed method is found efficient and effective in the evaluation of the morphological changes near a river mouth.
\end{abstract}

Keyword: river mouth, water level variation, linear regression, correlation, morphology changes, The Great East Japan Tsunami of 2011 


\section{Introduction}

The 2011 Tohoku Earthquake triggered a huge tsunami wave on 11 March 2011 as high as 40m in Iwate Prefecture, Japan (Mori et al., 2012), resulting in the tremendous casualties as well as the structural damages along the coast, which are reported by Suppasri et al. (2012). In addition, it has resulted in a massive morphology changes along the sandy coast of the Sendai Plain (Tanaka et al., 2012; Udo et al., 2012; Tappin et al., 2012). Adityawan et al. (2012) details the tsunami propagation process over land and the tsunami intrusion into rivers in Sendai Plain. According to Tanaka et al. (2012), breaching of coastal barriers is one of the typical features of tsunami-induced morphology changes along the Sendai Coast. The breaching caused devastating damages to the lagoon area along the coast. Besides being a natural environment, the lagoon area on the Sendai Coast has additional importance for breeding of the juvenile fish within the area (Omori et al., 1976; Malloy et al., 1996; Yamashita et al., 2000). For example, Yamashita et al. (2000) indicated that estuaries on the Sendai Coast play a significant role as nursery grounds for stone flounder, producing about half of the stock in spite of the small and restricted area compared to a wide expanse of the exposed inshore area.

The Gamo Lagoon is one of the lagoons on the Sendai Coast that was severely affected by the tsunami. The lagoon is located on the left side of the Nanakita River mouth. The lagoon and the river mouth experienced various morphology changes during the post tsunami period. These changes include the reformation of the sand barrier, the complete closure of the river mouth, the reformation of the river mouth in the lagoon, and an artificial straightening of the river mouth. Tanaka et al. (2012) reported the morphology changes during the period after the tsunami until the river mouth closure, whereas the present paper focuses mainly on the morphology changes after the river mouth blockage. Aerial-photographs as well as the water level data were used to monitor the morphology changes at the river mouth. The results showed that the water level data are highly effective for a detailed assessment of the morphology changes at the river mouth.

\section{Study Site and Methodology}

The rivers in Japan are classified into Class A and Class B dependent on their dimension as well as their social importance. The former belongs to the national government, while the latter belongs to the prefectural government. The study area is the Nanakita River classified as Class B that flows through the Sendai City in the Miyagi Prefecture located in the north-east of Japan as shown in Fig.1. The length and catchment area of the river 
are $229 \mathrm{~km}^{2}$ and $45 \mathrm{~km}$, respectively. The flood discharge of 100 -years return period is $1,650 \mathrm{~m}^{3} / \mathrm{s}$ and the average river discharge is about $10 \mathrm{~m}^{3} / \mathrm{s}$. Aerial-photos around the Nanakita river mouth have been being continuously taken at one or two-month interval for monitoring the morphology changes after the Great East Japan Tsunami of 2011 (Tanaka et al., 2012).

The Nanakita River mouth is located at the Coast of Sendai City. The coast is sandy beach and stretch about $12 \mathrm{~km}$ from Sendai Port at north until Natori River at south. It has northward littoral sediment movement due to predominant wave direction from ESE and SE (Tanaka and Takahashi, 1995). Pradjoko and Tanaka (2010) analyzed a series of aerial photograph using Empirical Orthogonal Function (EOF). They concluded that the shoreline dynamics was affected by the seasonal changes with the south of the river mouth being more stable. The shoreline at the north side of the river mouth was more dynamic since it is bounded by the breakwater near the Sendai Port (Ritphring and Tanaka, 2007).

Gamo lagoon is located at the north of the river mouth. This lagoon is separated from the sea by a sand barrier. Wave overtopping occasionally occurs and brought sediment deposits into the lagoon as reported by Tanaka et al. 2002. However, the sand barrier was never completely flushed as it was due to the tsunami of 2011, which is described later in this study.

The locations of the water level measurement stations G2, X1, and Yuriage, and availability of the data, are shown in Fig. 2 and Table 1 respectively. Unfortunately, tidal measurement station at the Sendai Port was damaged by the tsunami. In this study, the water level data at Yuriage Station in the Natori river mouth, at approximately $10 \mathrm{~km}$ from the Nanakita river mouth, is regarded as the sea tide. The Natori river mouth has no obstruction such as elongated sand spit, and it connects directly to the sea through the training jetties, which allows the tidal level propagates into the river without significant changes (Tanaka et al., 2000). A comparison of the water level at Sendai Port and the measurement at the Yuriage station as shown in Fig. $\mathbf{3}$ is found good.

The Nanakita river mouth and the Natori river mouth are connected each other by the Teizan Canal as also shown in Fig. 2. Although the two rivers are connected, a lock gate separated them as can be seen in Fig.2 and Fig. 4(a). Tanaka and Shuto (1992) made a detail measurement of the water level and the velocity at the Nanakita river mouth. At the time of the study, the lock gate was kept partially open. Thus, a part of the river discharge was diverted into the Teizan canal. Moreover, the wave set-up caused the water level in the Nanakita river mouth to rise 
higher than that in the Natori River, resulting in a unidirectional flow along the Teizan Canal to the Natori River.

For this reason, sediment flushing at the river entrance was not effective. In addition, the residual tidal flow may cause sediment deposits in the river mouth. Because of which, the river mouth blockage at the Nanakita River occurred frequently until the 1990s (Tanaka et al., 1996). The blockage was significantly reduced after the full closure of the lock gate.

The lock gate was severely damaged by the tsunami (Fig.4(b)). The destruction of the lock gate is closely related to the formation of a bar near the river mouth, as is described later in this study. The river mouth might not have been closed if the river discharge is maintained by closing the lock gate. However, because the lock gate was destroyed, the water diverted from the Nanakita River to the Natori River through Teizan Canal. In addition, the tsunami damaged the water level measurement stations. Shortly after the tsunami, the water level measurement resumed at the G2 station, located in the Teizan Canal. The water level at this station was the same with the Nanakita River since both channels are connected. The temporary restoration of the gate was conducted from the beginning of October, 2011 and completed soon after. The G2 station did not connect to the Nanakita River anymore after this restoration. Thus, the water level measurement at G2 was no longer suitable to represent the water level data in the Nanakita River. However, a new measurement station in the Nanakita River (X1) was installed at the left bank side of the river on November 24, 2011. Starting from that date, X1 station was used as the water level data in the Nanakita River mouth as described in Table $\mathbf{1 .}$

\section{Results and Discussions}

\subsection{River mouth morphology change}

The morphology changes at the Nanakita River mouth before and after the tsunami is shown in Fig. 5, of Fig. 5(a) through Fig. 5(e) have already been reported in Tanaka et al. (2012). Fig. 5(a) shows the morphology of the river mouth and the lagoon five days before the tsunami. The predominant movement of the longshore sediment is towards the north, resulting in the development of a spit from the right bank as seen in the Fig. 5(a). There is a jetty on the left-hand side of the river mouth to prevent migration of the river opening further to the left.

Fig. 5(b) shows the river mouth condition immediately after the tsunami on March 12, 2011. The sand barrier and the sand spit at the river entrance were severely eroded by the tsunami overflowing as well as by the 
strong return flow. The jetty structure on the left side is clearly visible due to the sand erosion around the structure. The structure was damaged at most part. Subsequently, the sand barrier that separates the sea and the lagoon was gradually reformed as observed in Fig. 5(c) and Fig. 5(d). In addition, the multiple sand spits at the river entrance developed on the right side of the mouth. Intrusion of the sand spits into the river upstream is distinct and different from the initial condition seen in Fig. 5(a). A similar feature has been observed at the Naruse River after the tsunami of 2011, as reported by Tanaka et al. (2012). The river bed at the Naruse River mouth in Miyagi Prefecture, Japan was eroded as deep as 8 m (Kitakami-Karyu River Office, 2012). Additionally, Tanaka et al. (2012) reported that the Natori River mouth in the same prefecture also eroded up to $10 \mathrm{~m}$. Unfortunately, bathymetry data is not available at the Nanakita River mouth. However, it is plausible to assume that the Nanakita River mouth was also eroded by several meters, extremely exceeding the ordinal water depth of $1.5 \mathrm{~m}$ (Srivihiok, 2005). Therefore, it is inferred that the sand spit reformation intruding far upstream as seen in Figs.5(c) and (d), instead of extrapolating linearly from the adjacent coastline on the right side, is attributed to the severe deepening of the river bed due to the propagation of the tsunami. Adityawan and Tanaka (2013) reported similar sand spit intrusion upstream after the tsunami at the Samegawa River, Fukushima Prefecture, Japan. The longshore sediment transport that carries sediment supplies will be transported and deposited further upstream causing the intrusion of the sand formation. The deposition location will depend on the contour of the river mouth as well as the river discharge. If the Teizan Canal remains open, the Nanakita River discharge may divert through this canal, as explained in the previous section. The river mouth may be completely closed since there is not enough discharge from upstream to keep the river mouth open.

The gate that separates the Nanakita River from the Teizan Canal is crucial in maintaining the river mouth condition, as explained in the previous section. However, the lock gate was completely destroyed by the tsunami of 2011. After the tsunami, the river mouth blockage was identified and confirmed on August 10, 2011 (Kahoku Shinpo, 2011). The aerial-photo taken shortly after the blockage is shown in Fig. 5(e). The fresh water discharge took placed from the Nanakita River to the Natori River through the Teizan Canal after the blockage. Therefore, the sand deposits at the blockage remained stable.

A flood occurred on September 22, 2011, caused by the typhoon No. 15. The flood caused the breaching of the sand barrier that leads to a new river mouth formation as shown in Fig. 5(f). However, the morphology 
change from the initial straight river mouth configuration to the non-straight configuration was inappropriate from the viewpoint of rapid drainage during a flood. In addition, the newly formed river mouth morphology was undesirable for preserving brackish water environment in the lagoon. Therefore, excavation was carried out by the local government at the location of the former river mouth opening early in March 2012, after the reconstruction of the jetty to separate the Gamo Lagoon and the Nanakita River (Fig. 5(g)). The excavated opening is stable up to now as shown in Fig. 5(h) and 5(i), whereas the opening created by the flood has closed naturally due to the decrease of fresh water discharge and tidal discharge.

\subsection{Water level data analysis}

Water level variation in a river mouth in response to tide is affected by the river mouth morphology such as its width and depth at its entrance. This process has been shown theoretically by numerous analytical solutions (e.g., Keulegan, 1967; Mehta and Özsoy, 1978; Escoffier and Walton, 1979; Walton and Escoffier, 1981). Numerical model was also widely used to analyze this phenomenon (Shuttleworth et al., 2005; Oliveira et al, 2006; McLean and Hinwood 2010). The river mouth morphology also affects the water level rise in a river mouth caused by the wave set-up (Oliveira, et al., 2006; Tanaka et al., 2008; Malhadas et al., 2009; Olabarrieta, 2011). In this study, a detailed analysis on the water level data at the river mouth was conducted, with an aim of assessing the river mouth morphological conditions during the period, when aerial-photographs are unavailable.

Fig. 6(a) shows the water level data on 6 July 2011, when the aerial-photo in Fig. 5(d) was taken. The tidal amplitude is slightly reduced in the Nanakita River mouth. However, the time variation shows a well correlated behavior between the water level in the sea and in the river. Hence, it is concluded that the tidal force intruded into the river mouth without any significant changes due to the negligibly small energy dissipation, although the development of the sand spit at the river mouth is observed in Fig. 5(d). It is possible that at this time, the water depth was adequate to allow tidal exchange.

Fig. 6(b) exhibits the water level data immediately prior to August 10, 2011, when the blockage was first observed by Kahoku Shinpo (2011), a local newspaper company. It is seen that during the high tide, the behavior of water level response in the river is similar to those illustrated in Fig. 6(a). During the low tide, however, the water level in the river was always higher than the tidal level. This result indicates formation of shallower water depth at 
the river mouth, causing more frictional resistance against tidal intrusion into the river. In addition, the river discharge is relatively small and thus, the effect of friction is more predominant when the water flows out from the river.

Fig. 6(c) denotes the water level data during the river mouth blockage shown in Fig. 5(e). The fresh water discharges from the river basin flowed through the Teizan Canal to the Natori River (see Fig. 2) due to the complete obstruction of the river mouth. The complete closure can be confirmed by the water level data that shows a remarkable phase delay as well as the distinct amplitude reduction as compared to the tidal variation is seen.

A flood on September 22 caused the opening of the river mouth as shown in Fig. 5(f). The water level data around the flood event is given in Fig. 6(d). Prior to the flood, the water level data comparison shows similar trend to those observed, and previously explained for Fig. 6(c). The flood caused a high discharge from the catchment area, with the highest water level of $1.92 \mathrm{~m}$ above MSL. After the flood, the phase delay decreased distinctly due to the new river mouth formation shown in Fig. 5(f).

As shown in Fig. 5(g), an excavation up to 1 meter depth was carried out to restore the river mouth to its original location, and was completed on March 3, 2012. The water level data prior and after the excavation are shown in Fig. 6(e) and Fig. 6(f), respectively. During both the periods, the river and the sea are closely correlated, though the water level after the excavation shows a better correlation due to the straightening of the river channel.

Due to the excavation in March 2012, the river has been stabilized to its original course as seen in Figs. 5(h) and 5(i).

\subsection{Estimation of the Date of the River Mouth Blockage}

It has been shown that the water level reflects the morphology condition at the river mouth. Nevertheless,

a better understanding of the morphology changes requires a more quantitative analysis. Therefore, quantitative evaluations on the relation between the water level in the river and the tidal level at sea are conducted to estimate the date of the river mouth blockage.

The correlation coefficient $(R)$ between the water level at the river mouth and the tidal level at sea was calculated, considering the modification of water level variation in the river mouth with the decrease of the cross-section. This parameter will detect the existence of phase lag between the datasets. Additionally, a gradient 
coefficient $(a)$ is calculated, which is defined as the gradient of the linear regression of the water level data following the relation below.

$$
\eta_{R}=a \eta_{O}+b
$$

where $\eta_{R}$ is the water level in the Nanakita River mouth, $\eta_{O}$ is the tidal level in the sea, and $b$ is the constant. In a river mouth with no blockage, the water level in the river mouth is equal to the tidal level $(a=1)$. However, river mouth blockage causes the amplitude reduction of the tidal level in the river mouth, which will decrease the value of the linear gradient.

The linear regression analysis for several periods between June to September of 2011 is shown in Fig. 7. In addition, the daily gradient coefficient and the correlation coefficient are given in Fig. 8. Here, the box (a) to (d) in Fig. 8 corresponds to the water level data presented in Fig. 6, while the box (1) to (5) corresponds to the gradient coefficient analysis presented in Fig. 7.

The linear regression shows different behavior between each analyzed period, as shown in Fig. 7(1) to (5). The gradual process of the river mouth closure corresponds well to the decrease of the $a$ value. In addition, the gradient changes occur due to the inability of the water level in the river to follow the low water level at the sea. A full blockage of the river mouth causes the water level in the river to stop responding completely to the tidal level at sea. Hence, nearly zero linear gradients is observed as shown in Fig. 7(4).

The daily values of the $R$ and $a$ are shown in Fig. 8. The $R$ values in June 2011 mostly equal to 1.0. This indicates that the river mouth cross-section was sufficiently large, and the tidal exchange occurred without any obstruction. The condition agrees well with the severe erosion at the entrance due to the tsunami. The $R$ value decreases gradually from July to August. In addition, the minimum value of R occurs during the middle of August to the middle of September. The $R$ value increases after the flood event on September 22. The flood-induced opening of the river mouth, shown in Fig. 5(f), causes the drastic change of the $R$ value. Similar tendency is observed for the gradient coefficient (a) value. However, the $a$ value shows less fluctuation as compared to the $R$ value.

The river mouth was almost fully closed on August 9, 2011 as shown in Fig. 9. Here, Fig. 9(a) and (b) show the photos reported by Sato (2012) taken from the viewing angle as given in Fig. 9(c). The overflowing water may slightly occur during high tide on this date. The blockage of the river mouth was first reported on 
August 10, 2011 as shown in Fig. 10 (Kahoku Shinpo, 2011). This local information confirms that the complete blockage that occurred on August 10. A significant decrease of the $R$ and $a$ value was observed on that date with no further increase in the following days, as can be seen in Fig. 8. Therefore, the correlation coefficient as well as linear gradient value can be used as an index to determine the river mouth blockage.

\subsection{Effect of excavation}

It has been confirmed that the river mouth blockage can be determined from the water level data. Thus, it is expected that the improvement of the river mouth condition by excavation in March, 2012, is also reflected in the water level changes. Therefore, a similar analysis as discussed in the previous sub-section was conducted using the water level data from February to March in 2012.

The daily gradient coefficient $(a)$ and the correlation coefficient $(R)$ around the time of the excavation are shown in Fig. 11. It is found that both the $R$ and $a$ values are lower prior to the excavation. It is shown in Fig. 5(f) that the flood-induced river mouth is located further to left side, whereas, the excavated river mouth was directly connected to the sea as can be seen in Figs. 5(h) and 5(i). The higher $R$ and $a$ value confirm that the tidal exchange has increased through the new river mouth.

\section{Conclusions}

The morphology changes at the Nanakita river mouth after the Great East Japan Tsunami of 2011 on 11 March have been observed based on monthly or bimonthly the aerial-photos. In addition, water level data were used to complement the aerial-photos for assessing the morphology changes near the river mouth in details.

The correlation coefficient $(R)$ and the linear gradient coefficient $(a)$ between the water level data in the river and in the sea were analyzed. Both the parameters are found to be high after the tsunami. This corresponds to large cross-section of the river mouth due to the severe erosion caused by the tsunami. The river mouth development during the recovery process was assessed. It was found that the sandbar from the longshore sediment movement, along the upstream of the river mouth. The Nanakita river mouth was completely closed for a period of time due to the sediment movement and the destruction of the lock gate. The proposed statistical parameters successfully estimated the time of a river mouth closure. Subsequently, a flood event created a new river mouth 
that connects the river to the sea. This condition was reflected in the increase of the $R$ and $a$ values Nevertheless the flood-induced river mouth was located further to the left from its original location. Therefore, excavation was conducted to restore it. The excavation created a more direct connection to the sea which was shown in the higher values of $R$ and $a$.

This study has shown that the daily variation of the correlation coefficient and the gradient coefficient can be used to monitor the river mouth condition. However, the method presented in this study was tested only for a small river (Nanakita River). Therefore, it is necessary to conduct further verification for larger rivers under different conditions. Future study may combine data from other rivers, numerical model, as well as experimental works to further verify the proposed method. In addition, a detail study on bathymetry data around the river mouth may yield a way to correlate the statistic parameters with the amount of bed change.

\section{Acknowledgement}

The authors wish to express grateful thanks to the Miyagi Prefectural Government and the Ministry of Land, Infrastructure and Transport for providing us the precious water level data. This research could not be conducted without financial supports from JST/JICA, SATREPS (Science and Technology Research Partnership for Sustainable Development), the Grant-in-Aid for Scientific Research from JSPS (No. 22360193, No. 2301367), Grant-in-Aid for Scientific Research from the River Environmental Fund (REF) in charge of the Foundation of River and Watershed Environmental Management (FOREM), as well as Assistance for Technological Development, Tohoku Construction Association. The authors would like to gratefully appreciate their supports.

\section{References}

Adityawan, M.B., Roh, M., Tanaka, H., Mano, A., Udo, K., 2012. Investigation of tsunami propagation characteristics in river and on land induced by The Great East Japan Earthquake 2011. Journal of Earthquake and Tsunami, 6(3), 1250033, 22 pages.

Adityawan, M.B., Tanaka, H., 2013. Assessment of the morphological changes at the Samegawa River Mouth, Japan. Proceedings of The 12th International Symposium on River Sedimentation (ISRS2013).

Escoffier, F.F., Walton, Jr., T.L., 1979. Inlet stability solutions for tributary inflow. J. Waterways Harbors Div., 
ASCE WW4 (105), 341-355.

Kahoku Shinpo, 2011. The breath of the Gamo tidal flat revival, August 16, 2011 morning newspaper. (in Japanese)

Keulegan, G.H., 1967. Tidal flow in entrances: water level fluctuations of basins in communication with the seas. Committee on Tidal Hydraulics Technical Bulletin 14. US Army Engineers Waterways Experiment Station, Vicksburg, MS.

Kitakami-Karyu River Office, 2013. Private communication.

Malhadas, M. S., P. C. Leita o, A. Silva, Neves, R., 2009. Effect of coastal waves on sea level in O'bidos Lagoon, Portugal. Continental Shelf Research 29, 1240-1250.

Malloy, K.D., Yamashita, Y., Yamada, H., Timothy, E., 1996. Spatial and temporal patterns of juvenile stone flounder Kareius bicoloratus growth rates during and after settlement. Marine Ecology Progress Series $13149-59$.

McLean, E.J., Hinwood, J.B., 2000. Modelling entrance resistance in estuaries. Proc. 27th International Conference on Coastal Engineering, pp.3446-3457.

Mehta, A.J., Özsoy E., 1978. Inlet Hydraulics. In: Bruun, P. (ed), Stability of Tidal Inlets. Elsevier Scientific Pub. Com., pp.83-108.

Mori, N., Takahashi, T., The 2011 Tohoku Earthquake Tsunami Joint Survey Group, 2012. Nationwide post event survey and analysis of the 2011 Tohoku Earthquake Tsunami. Coastal Engineering Journal 54(1).

Olabarrieta, M., Warner, J.C., Kumar, N., 2011. Wave-current interaction in Willapa Bay, Journal of Geophysical Research, 116 (C12014).

Oliveira, A., Fortunato, A.B., Rego, J.R.L., 2006. Effect of morphological changes on the hydrodynamics and flushing properties of the O'bidos Lagoon (Portugal). Continental Shelf Research, 26, 917-942.

Omori, M., Kinno, H., Nishihata, I., 1976. Study of the habitat of juvenile stone flounder, Kareius bicoloratus (Basilewsky), in the Estuary of the Nanakita River, Tohoku Journal of Agricultural Research, 27(2), 79-91.

Ritphring, S., Tanaka, H., 2007. Analysis of topographic change in the vicinity of coastal structure using empirical orthogonal function, Proceedings of Asian and Pacific Coast, pp: 1112-1126. 
Sato, K., 2012. The Gamo investigation report, News Letter, Sendai Science Museum, http://www.kagakukan.sendai-c.ed.jp/news3/doc/No_18.pdf, Accessed on October 20, 2012. (in Japanese)

Shuttleworth, B., Woidt, A., Paparella, T., Herbig, S., Walker, D., 2005. The dynamic behaviour of a river-dominated tidal inlet, River Murray, Australia. Estuarine, Coastal and Shelf Science 64, 645-657.

Srivihiok, P., 2005. Study on river mouth morphodynamics responding to wave, tide and river flow, Dr. Engineering Dissertation, Department of Civil Engineering, Tohoku University, September, 2005.

Suppasri, A., Koshimura, S., Imai, K., Mas, E., Gokon, H., Muhari, A., Imamura, F., 2012. Damage characteristic and field survey of the 2011 Great East Japan Tsunami in Miyagi Prefecture, Coastal Engineering Journal 54(1).

Tanaka, H., Shuto, N., 1992. Field investigation at a mouth of small river. Proc. 23rd International Conference on Coastal Engineering, pp.2486-2499.

Tanaka, H., Takahashi, A., 1995. Short-term shoreline change on Sendai Coast. Computer Modeling of Seas and Coastal Regions, pp.205-212.

Tanaka, H., Takahashi, A., Takahashi, F., 1996. Complete closure at the Nanakita River mouth in 1994. In: Proc. of 25th International Conference on Coastal Engineering, ASCE, pp.4545-4556.

Tanaka, H., Nagabayashi, H., Yamauchi, K., 2000. Observation of wave set-up height in a river mouth, Proc. 27th International Conference on Coastal Engineering, pp.3458-3471.

Tanaka, H., Suntoyo, Nagasawa T., 2002. Sediment intrusion into gamo lagoon by wave overtopping. Proc. 28th International Conference on Coastal Engineering, pp.823-835.

Tanaka, H., Nguyen, X.T., Nagabayashi, H., 2008. Wave setup at different river entrance morphologies. Proc. 31st International Conference on Coastal Engineering, pp.975-985.

Tanaka, H., Nguyen, X. T., Umeda, M., Hirao, R., Pradjoko, E., Mano, A., Udo, K., 2012. Coastal and estuarine morphology changes induced the 2011 Great East Japan Earthquake Tsunami. Coastal Engineering Journal 54(1).

Tappin, D.R., Evans, H.M., Jordan, C.J., Richmond, B., Sugawara, D., Goto, K., 2012. Coastal changes in the 
Sendai area from the impact of the 2011 Tōhoku-oki tsunami: Interpretations of time series satellite images, helicopter-borne video footage and field observations. Sedimentary Geology 282(30), 151-174.

Udo, K., Sugawara, D., Tanaka, H., Imai, K., Mano, A., 2012. Impact of the 2011 Tohoku Earthquake and Tsunami on beach morphology along the northern Sendai Coast, Coastal Engineering Journal, 54(1).

Walton, Jr., T.L., Escoffier, F.F., 1981. Linearized solution to the inlet equation with inertia. J. Waterways Harbors Div., ASCE WW3, 191-195.

Yamashita, Y., Otake, T., Yamada, H., 2000. Relative contributions from exposed inshore and estuarine nursery grounds to the recruitment of stone flounder, Platichthys bicoloratus, estimated using otolith $\mathrm{Sr}: \mathrm{Ca}$ ratios. Fisheries Oceanography 9(4), 316-327. 


\section{Figure and Table captions}

Table 1 Measurement period of water level.

Fig. 1 Study area

Fig. 2 The Nanakita River mouth geographical feature and water level observation position (Google Earth).

Fig. 3 Comparison of water level variation in the sea and measurement at Yuriage.

Fig. 4 Lock gate at the conjunction of the Teizan Canal and the Nanakita River.

(a) Pre-tsunami photograph.

(b) Post-tsunami photograph.

Fig. 5 Aerial-photos at the Nanakita River mouth.

(a) March $6^{\text {th }}, 2011$.

(b) March 12 $2^{\text {th }}, 2011$.

(c) June $8^{\text {th }}, 2011$.

(d) July $6^{\text {th }}, 2011$.

(e) September $7^{\text {th }}, 2011$.

(f) September $24^{\text {th }}, 2011$.

(g) February 22 ${ }^{\text {nd }}, 2012$.

(h) March 14 $4^{\text {th }}, 2012$.

(i) April $8^{\text {th }}, 2012$.

Fig. 6 Temporal variation of water level.
(a) 2011, 5-12 July.
(b) 2011, 2-9 August.
(c) 2011, 6-13 September.
(d) 2011, 18-25 September.
(e) 2012, 7-14 February.
(f) 2012, 13-20 March. 
Fig. 7 Correlation between river mouth water level and tidal level.

(1) 2011, 24-30 June.

(2) 2011, 22-28 July.

(3) 2011, 10 August.

(4) 2011, 26 August-1 September.

(5) 2011, 27-30 September.

Fig. 8 Daily variation of $R$ and $a$ prior and after the river mouth blockage.

Fig. 9 Photos showing the almost full river mouth blockage on August 9th, 2011

(a) View 1 (Sato, 2012).

(b) View 2 (Sato, 2012).

(c) View point location.

Fig. 10 Aerial-photo showing the full river mouth blockage on August 10th, 2011 (Kahoku Shinpo, 2011)

Fig. 11 Daily variation of $R$ and $a$ prior and after the excavation. 
Table 1 Measurement period of water level variation

\begin{tabular}{c|c|l}
\hline Measuring station & $\begin{array}{c}\text { Starting date of } \\
\text { measurement }\end{array}$ & \multicolumn{1}{c}{ Note } \\
\hline \multirow{2}{*}{ G2 } & June 22,2011 & $\begin{array}{l}\text { Used as river mouth water level } \\
\text { until the separation of the } \\
\text { Nanakita River and Teizan } \\
\text { Canal in October, 2011. }\end{array}$ \\
\hline X1 & November 24, 2011 & $\begin{array}{l}\text { Used as river mouth water level } \\
\text { after the separation of the } \\
\text { Nanakita River and Teizan Canal } \\
\text { in October, 2011. }\end{array}$ \\
\hline Yuriage & April 1, 2011 & Used as tidal elevation. \\
\hline
\end{tabular}

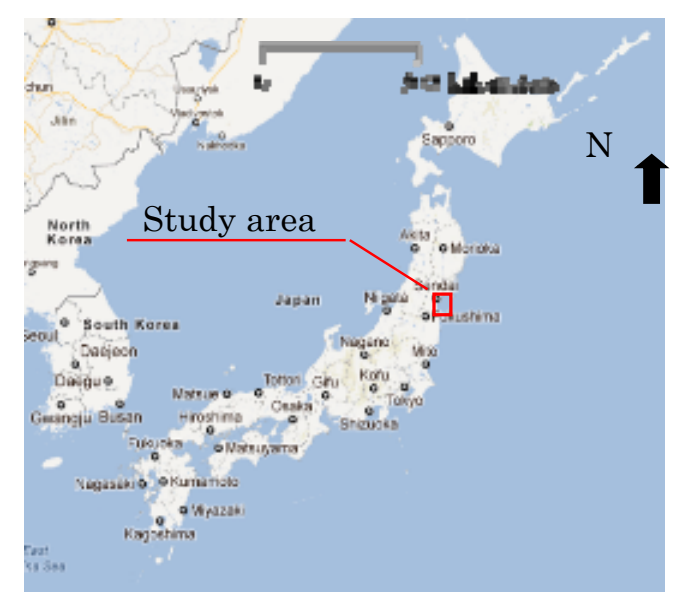

Fig. 1 Study area.

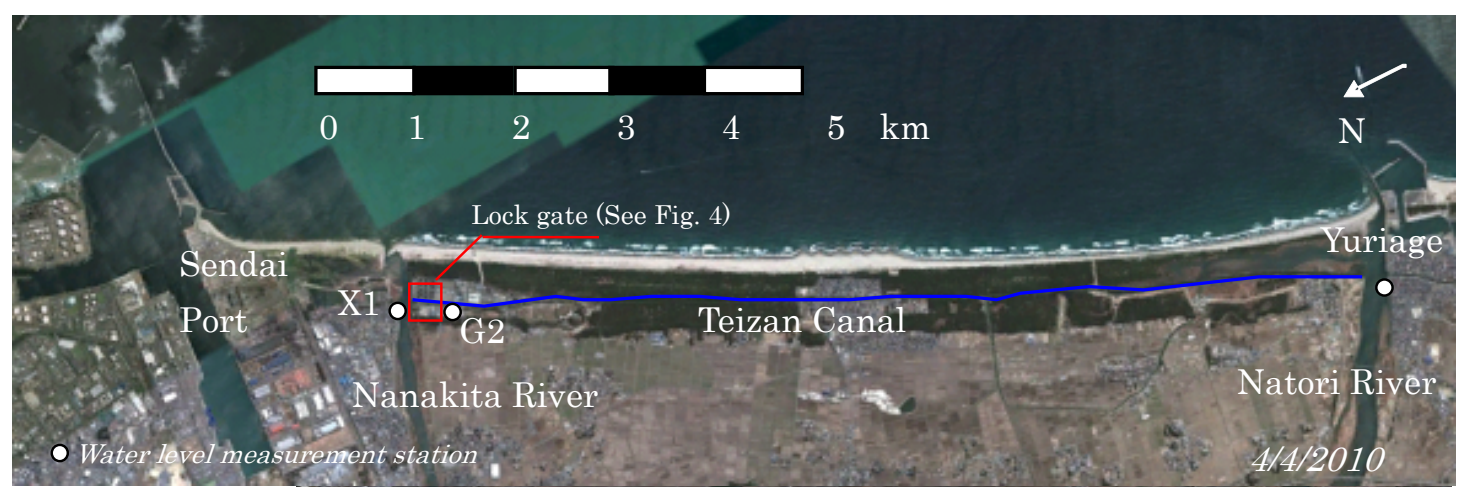

Fig. 2 The Nanakita River mouth geographical feature and water level observation position (Google Earth ). 


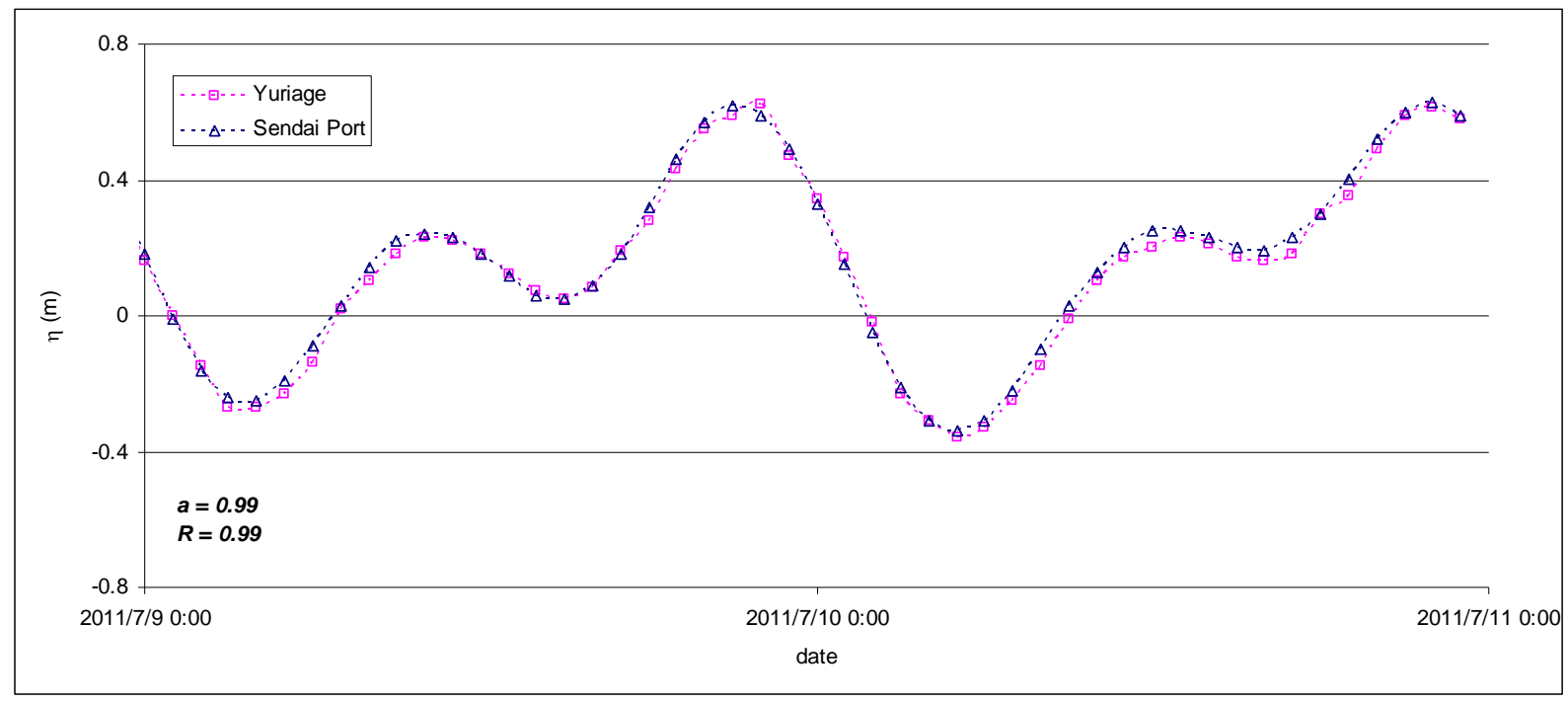

Fig. 3 Comparison of water level variation in the sea and measurement at Yuriage.

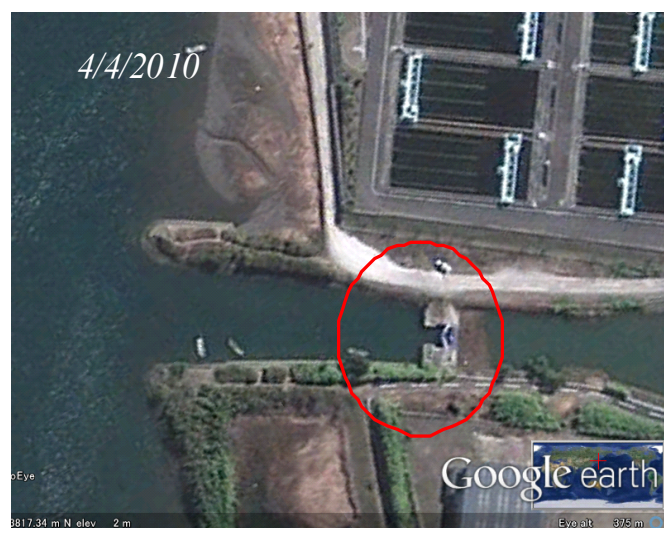

(a) Pre-tsunami photograph (Google Earth).

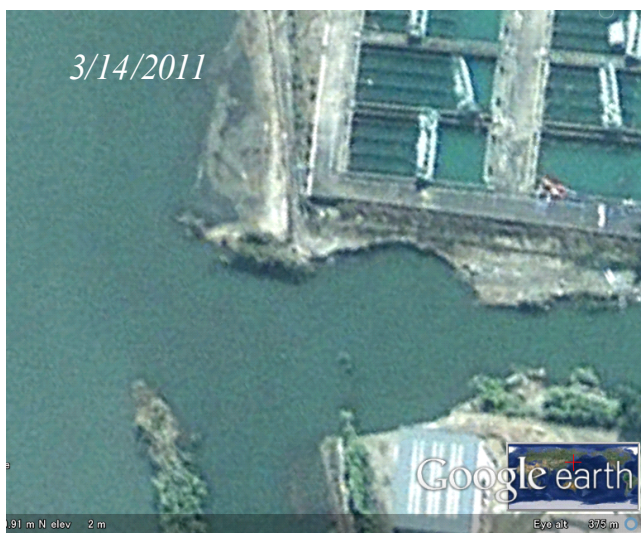

(b) Post-tsunami photograph (Google Earth).

Fig. 4 Lock gate at the conjunction of the Teizan Canal and the Nanakita River. 


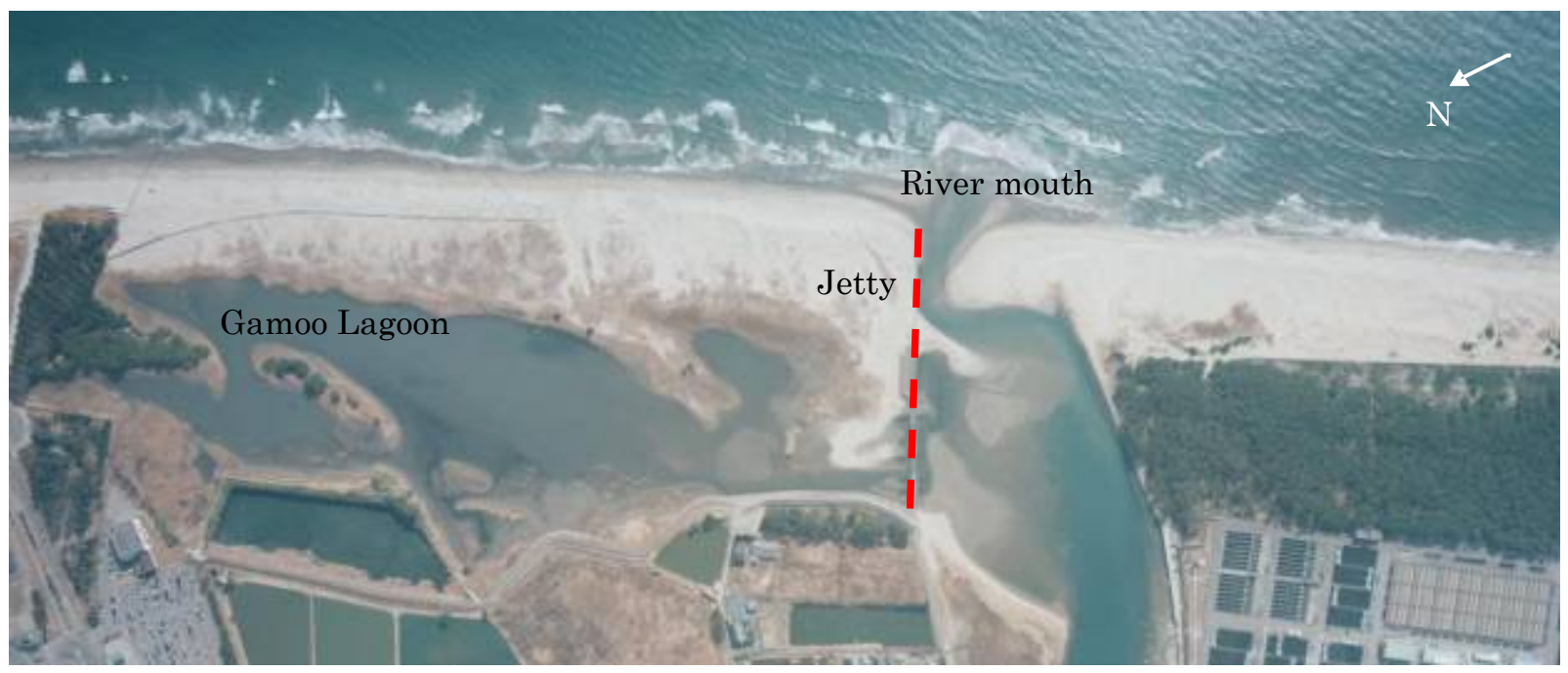

(a) March 6 $6^{\text {th }}, 2011$.

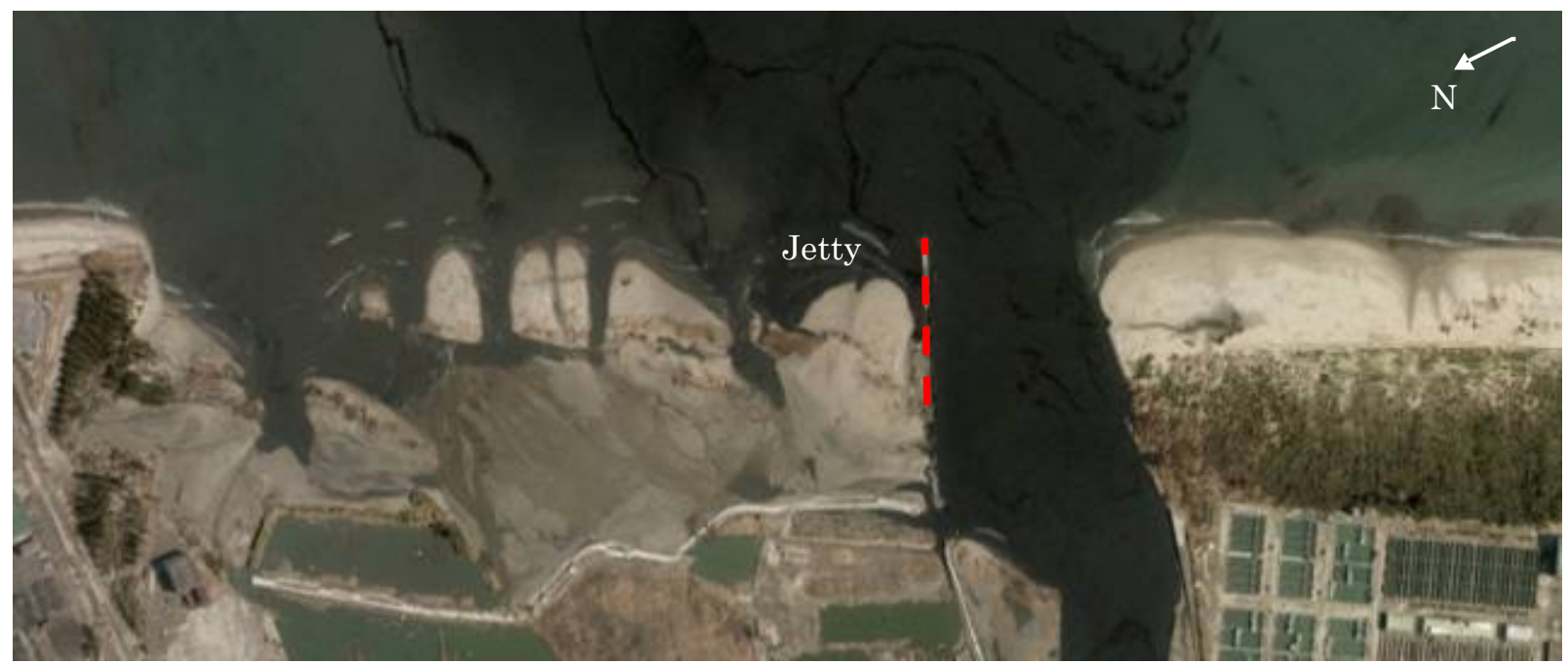

(b) March 12 $2^{\text {th }}, 2011$ (Geospatial Information Authority of Japan).

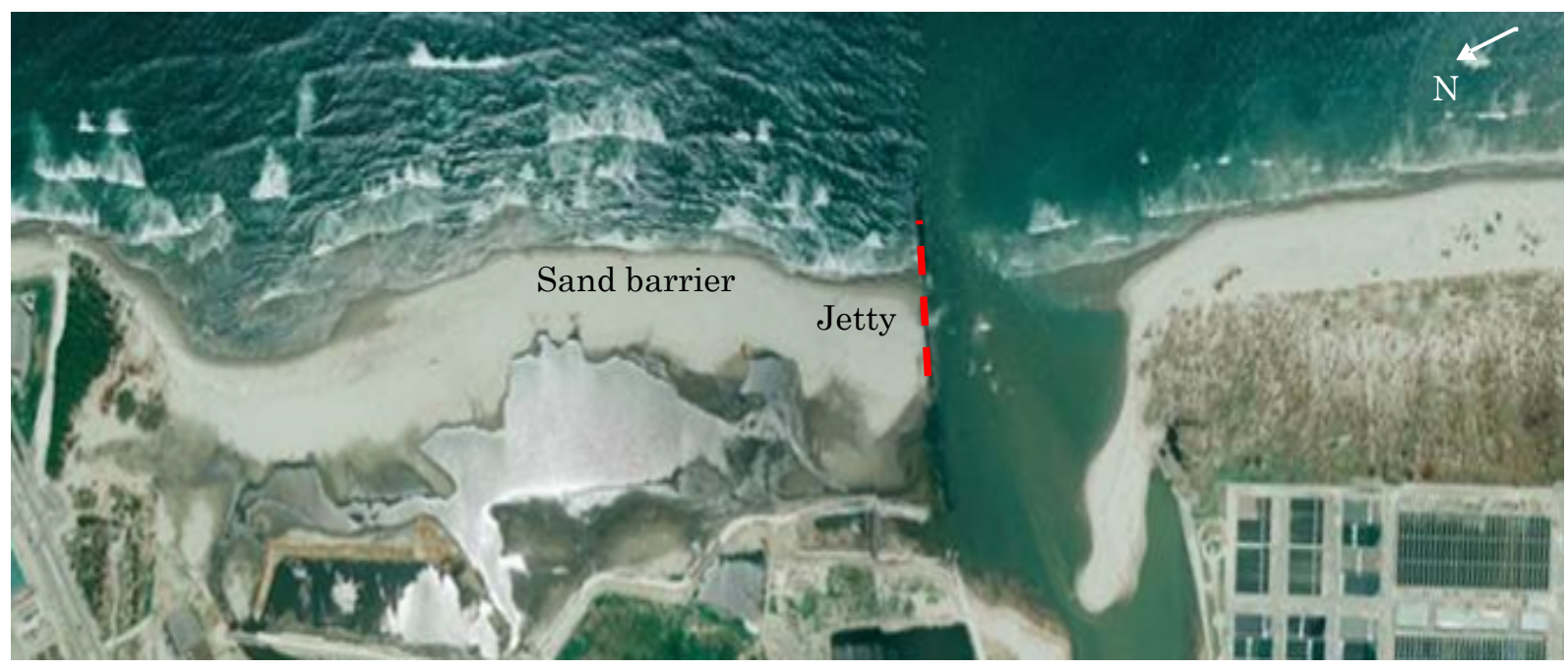

(c) June $8^{\text {th }}, 2011$.

Fig. 5 (for caption see next page) 


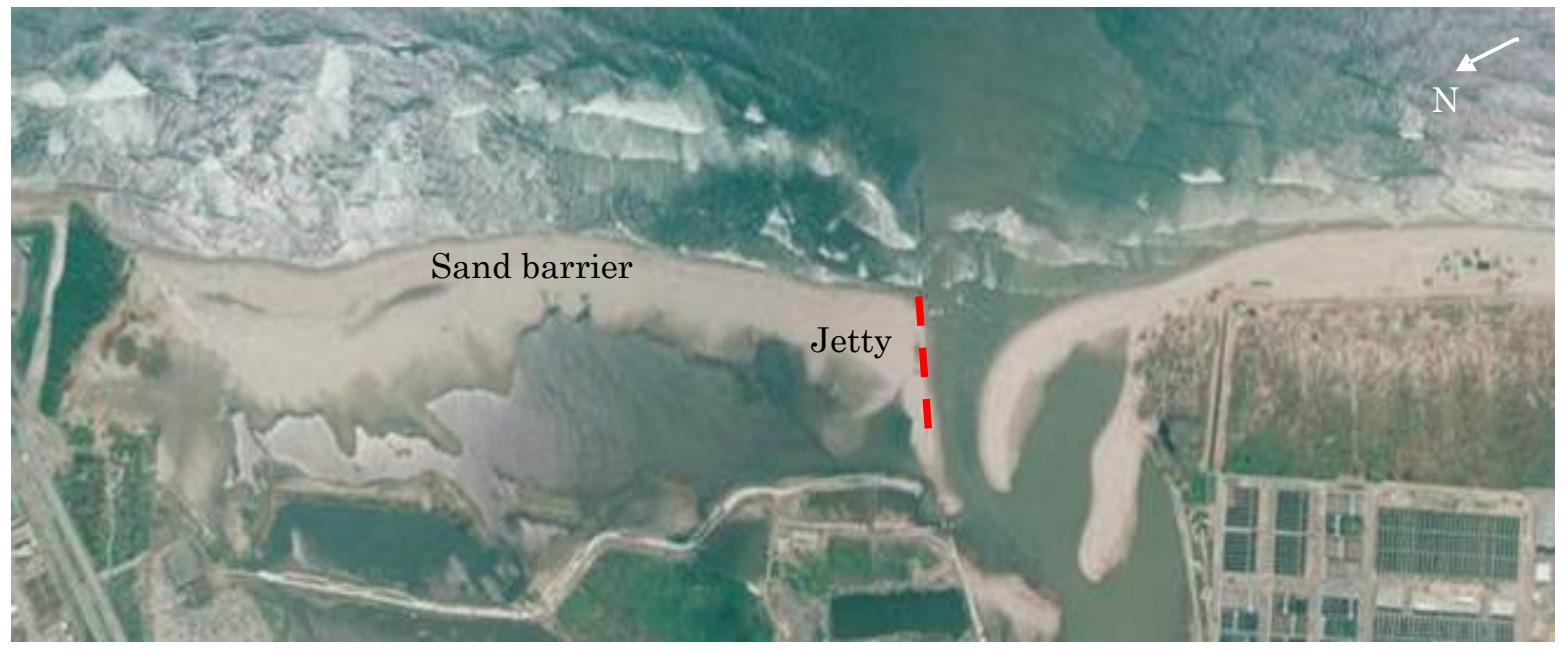

(d) July $6^{\text {th }}, 2011$.

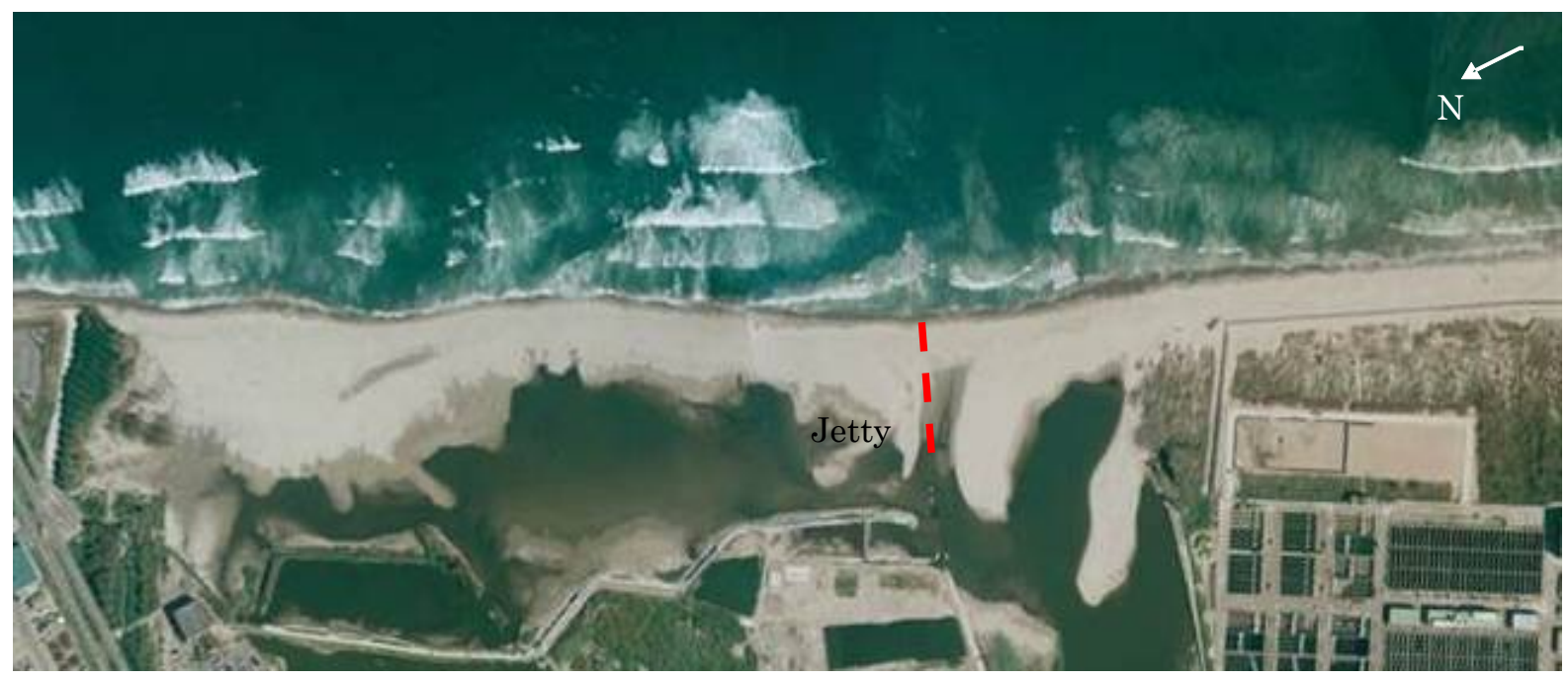

(e) September $7^{\text {th }}, 2011$.

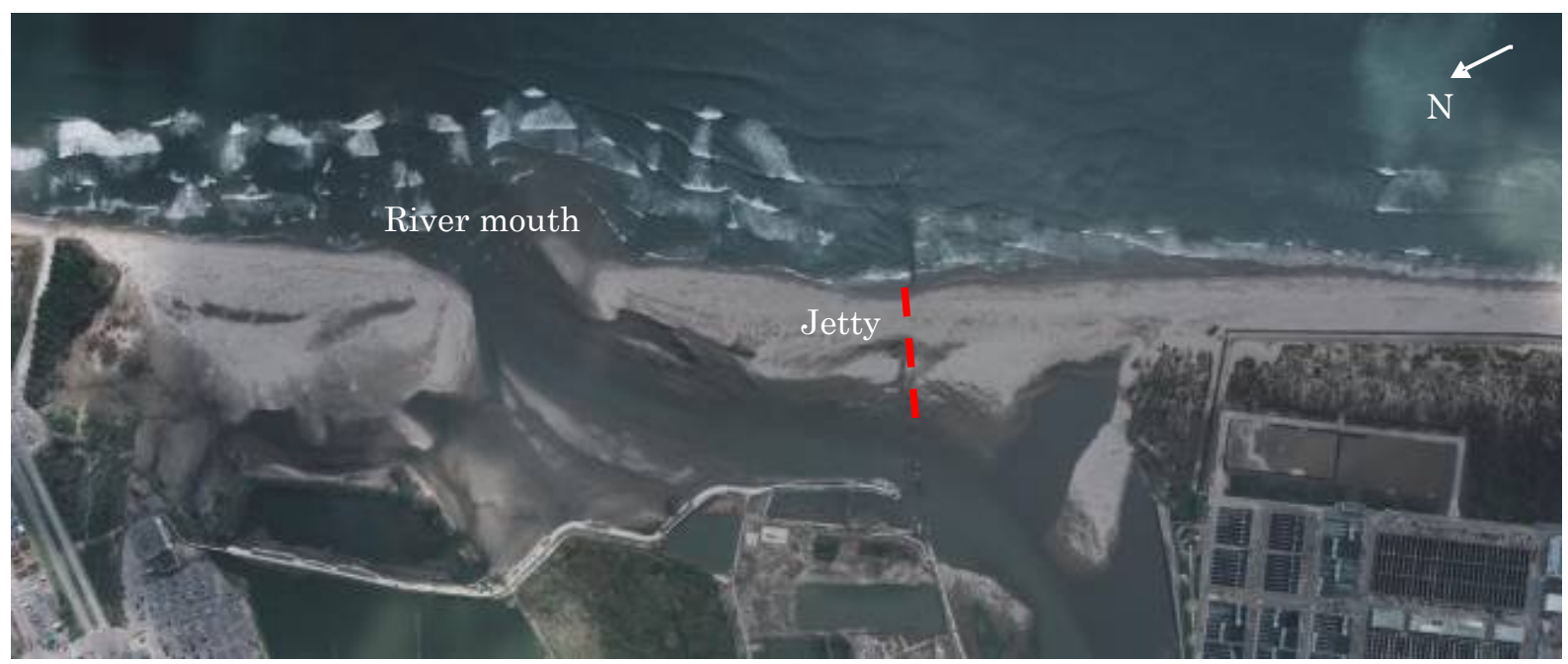

(f) September $24^{\text {th }}, 2011$.

Fig. 5 (for caption see next page) 


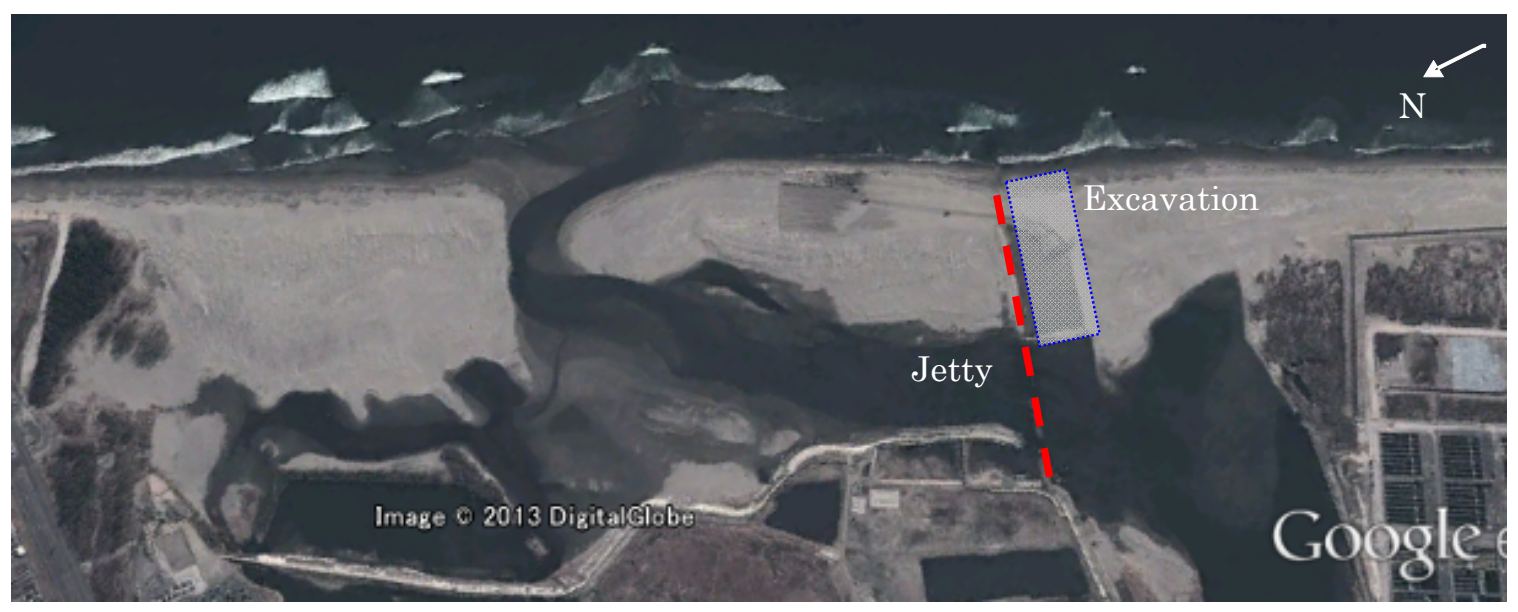

(g) February 22 ${ }^{\text {nd }}, 2012$ (Google Earth).

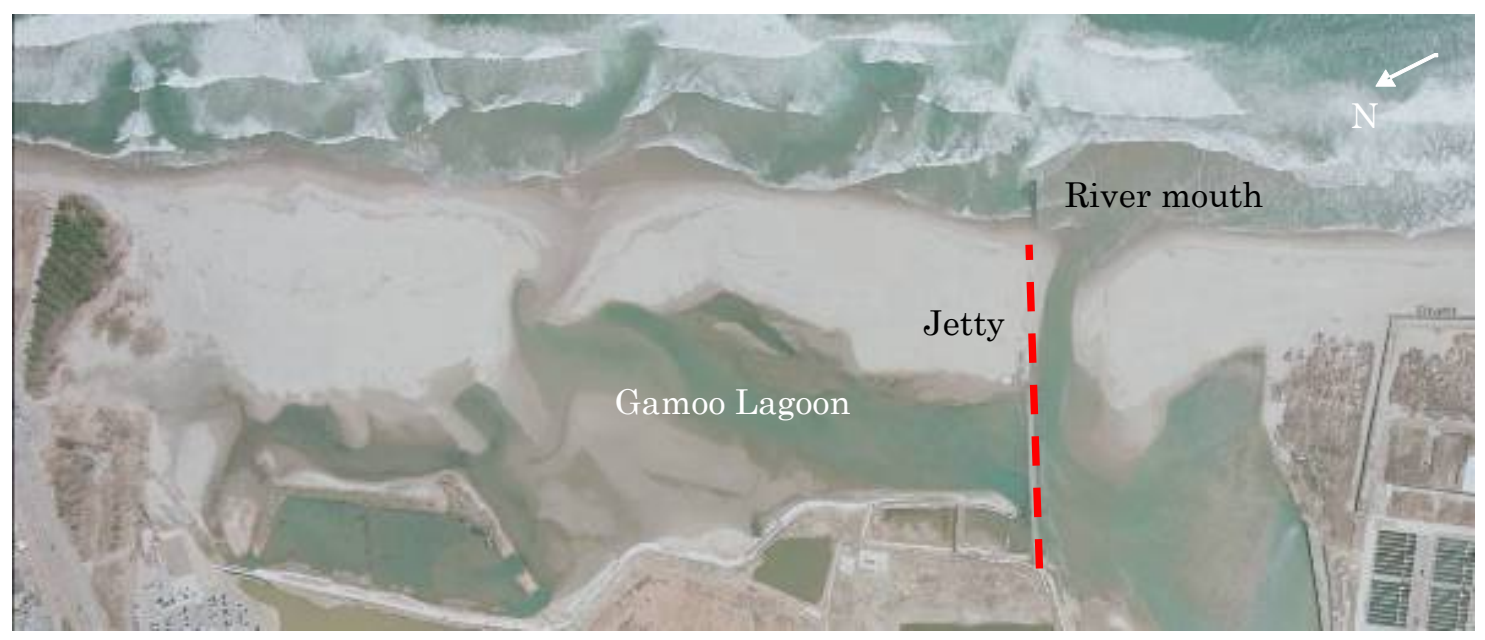

(h) March $14^{\text {th }}, 2012$.

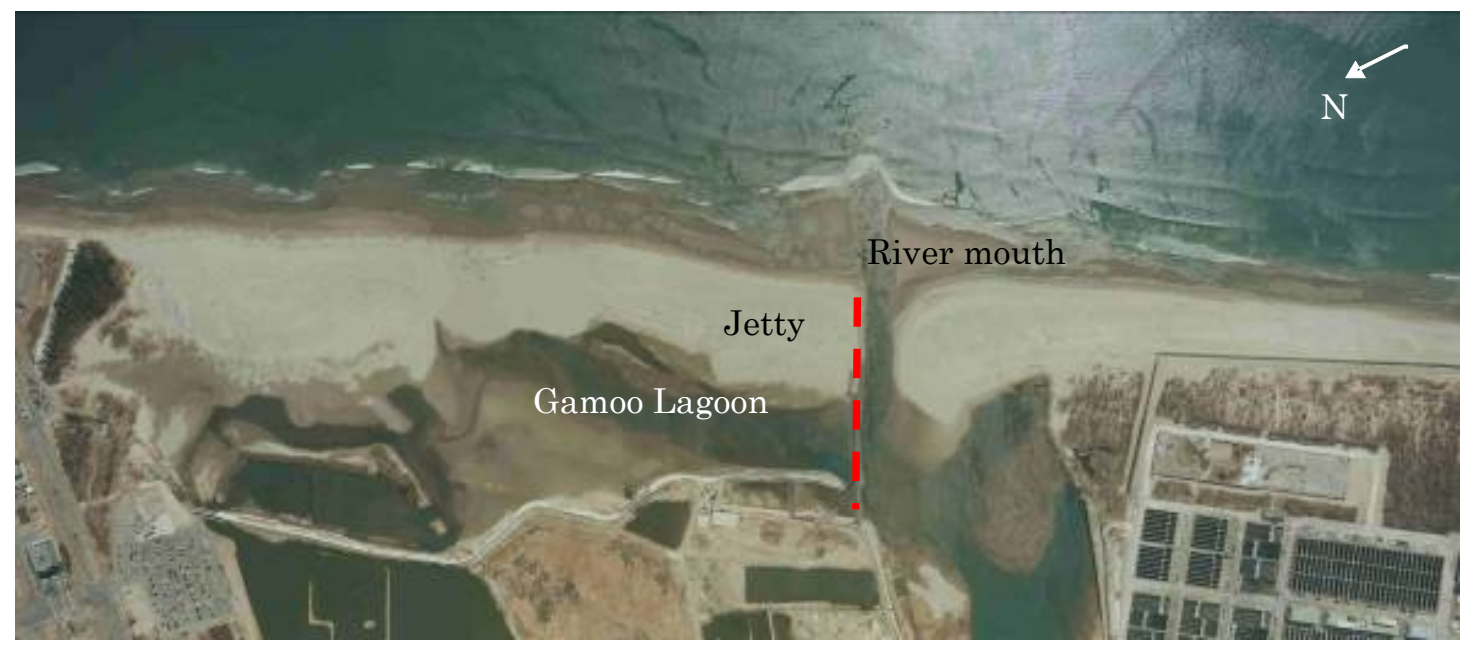

(i) April $8^{\text {th }}, 2012$.

Fig. 5 Aerial-photos at the Nanakita River mouth. 


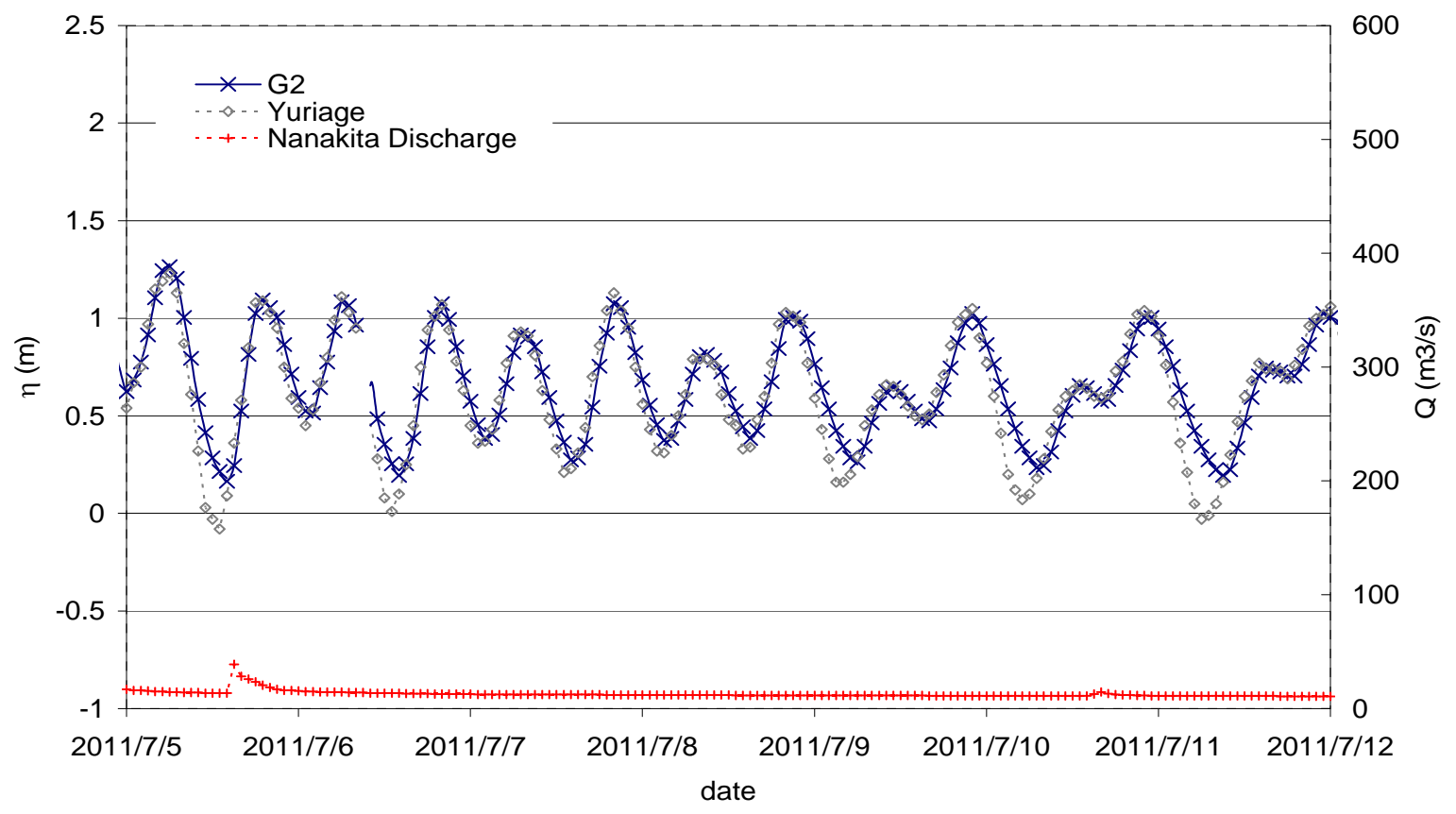

(a) 2011, 5-12 July.

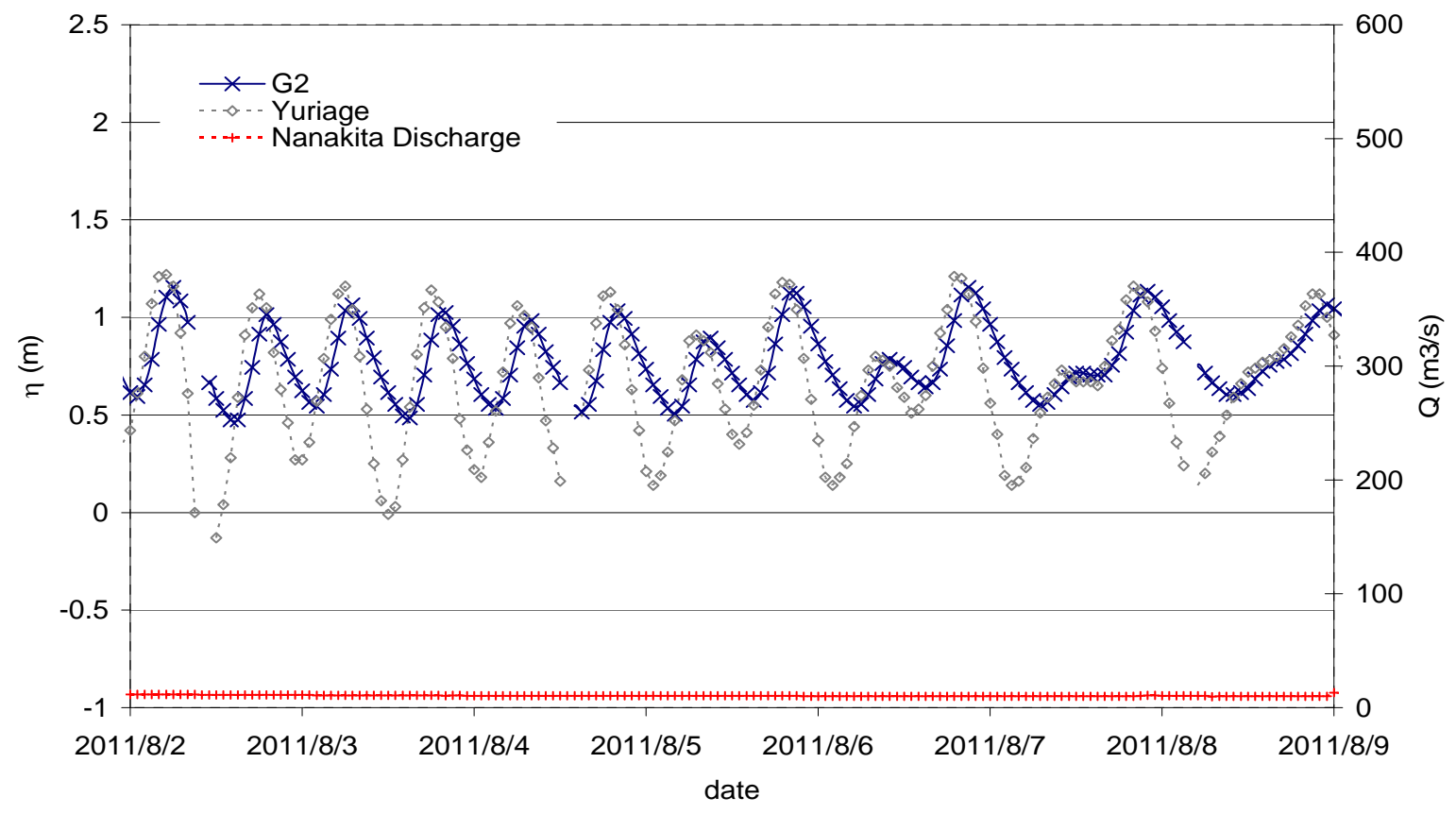

(b) 2011, 2-9 August.

Fig. 6 (for caption see next page) 


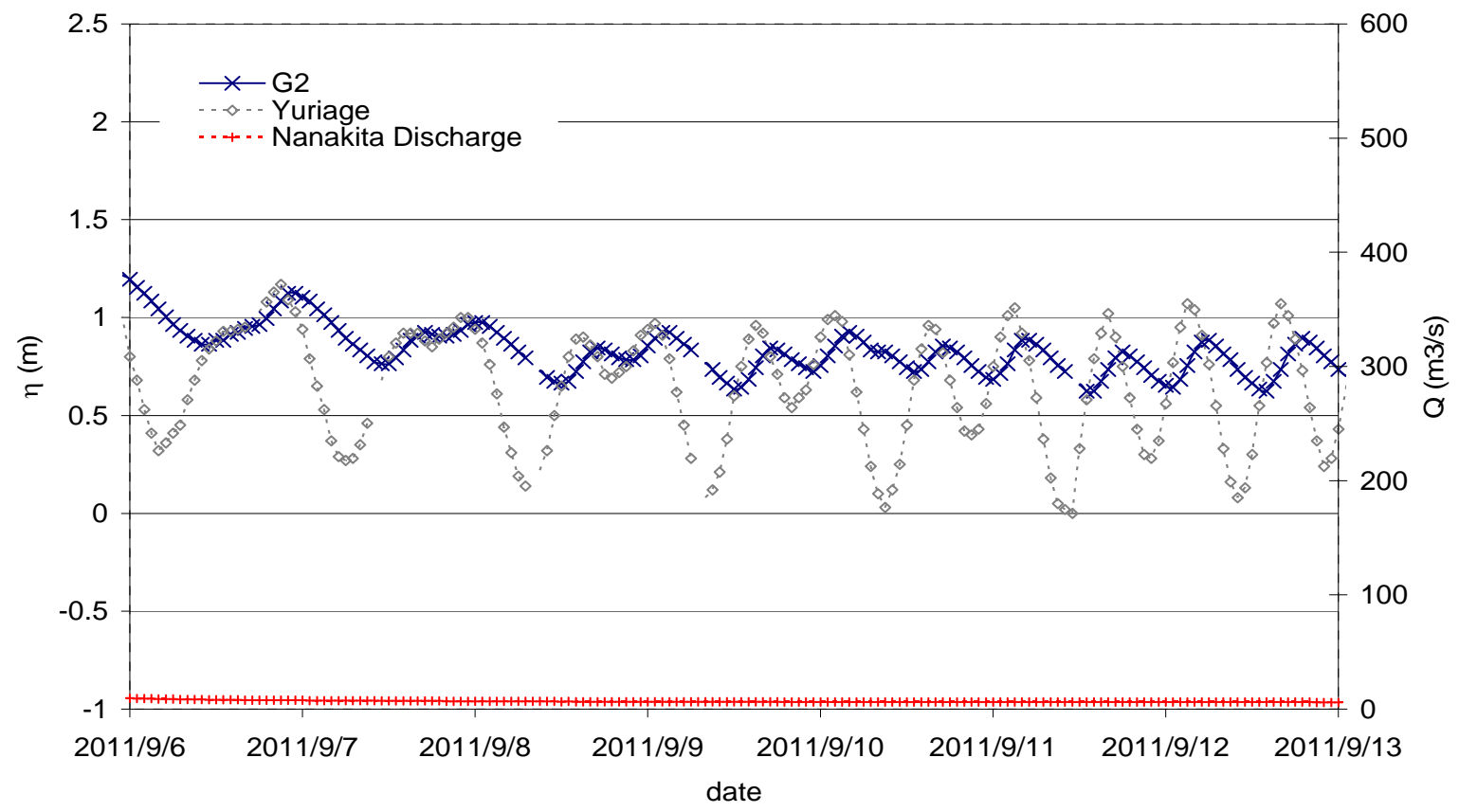

(c) 2011, 6-13 September.

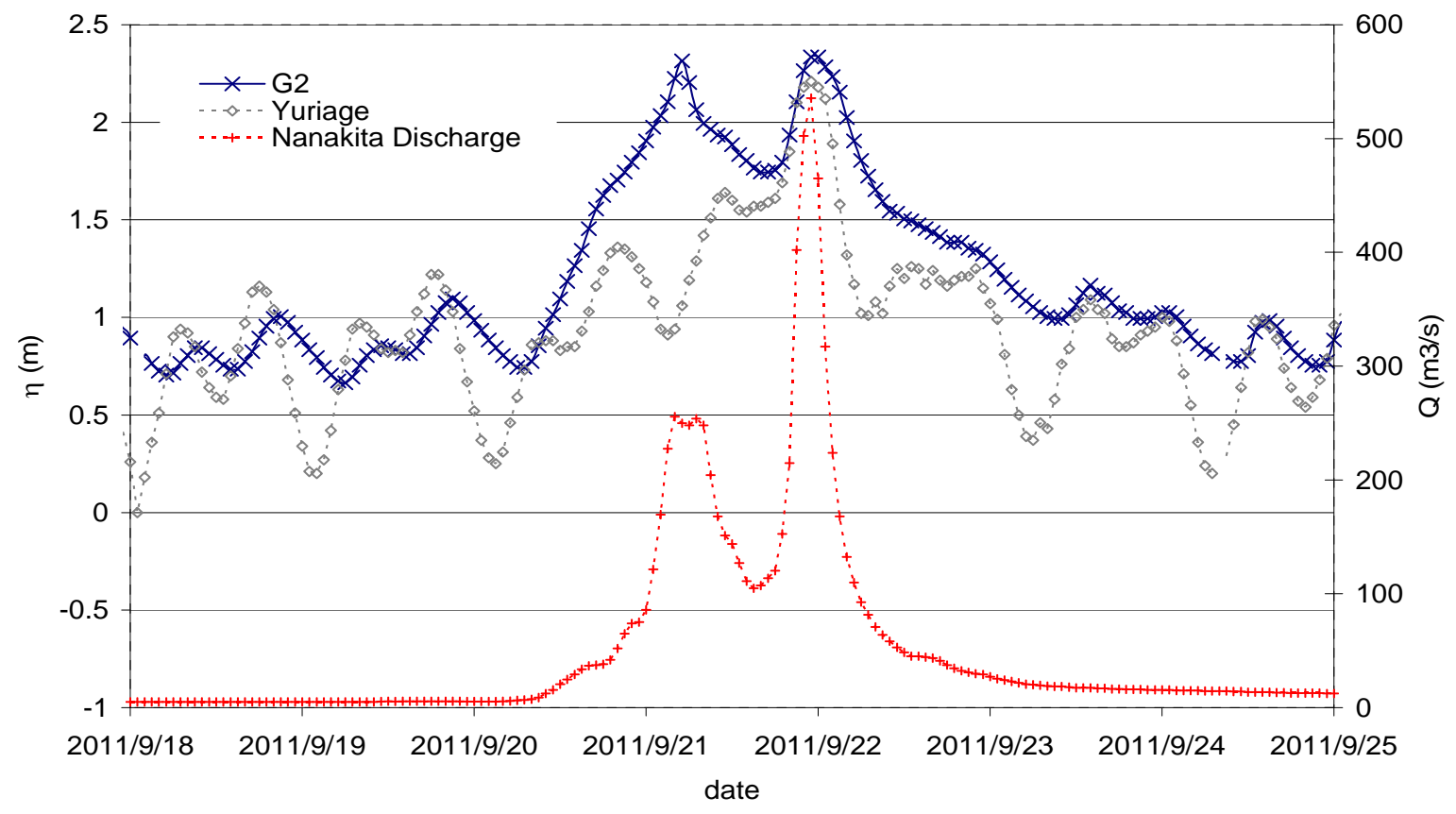

(d) 2011, 18-25 September.

Fig. 6 (for caption see next page) 


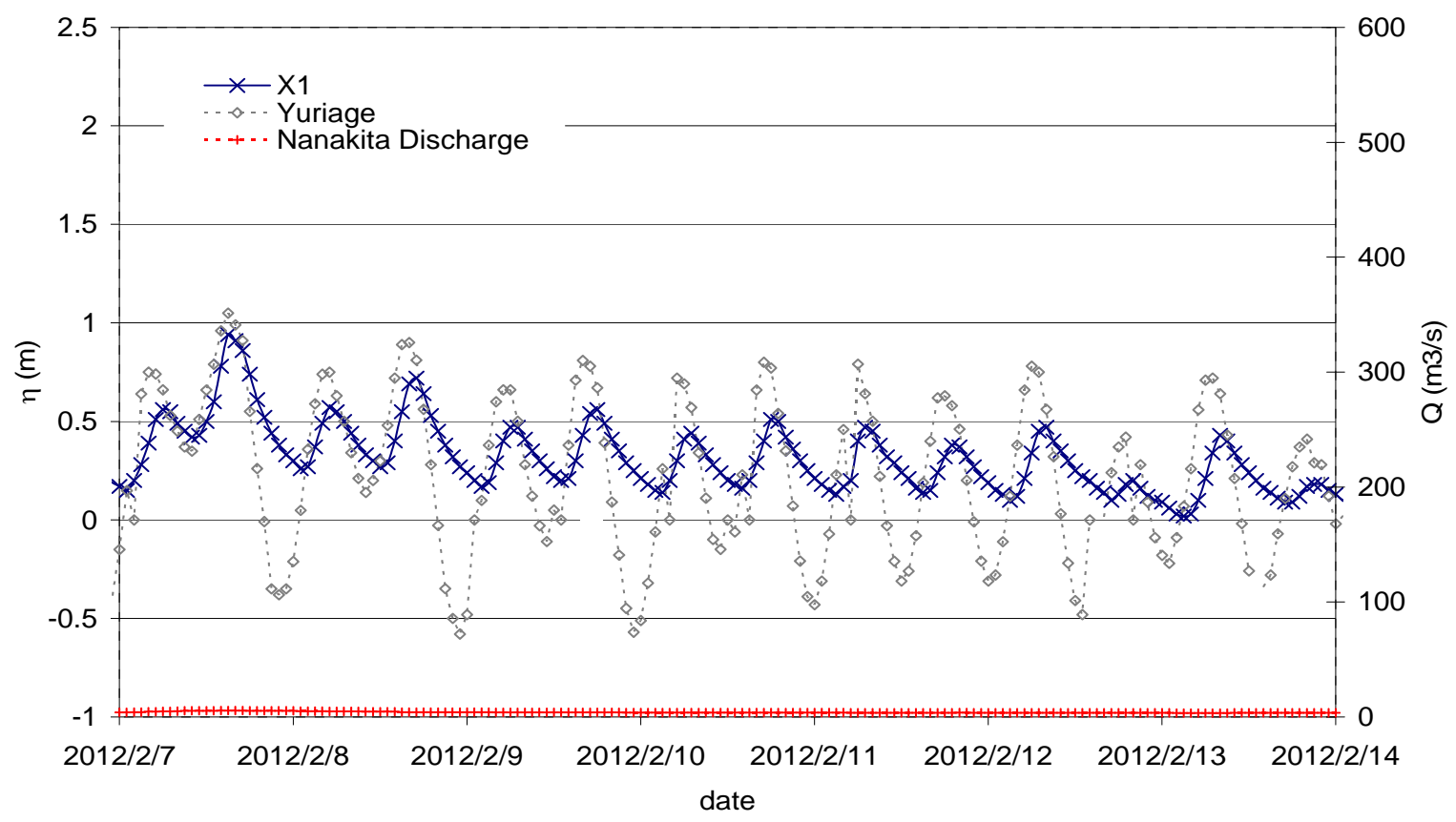

(e) 2012, 7-14 February.

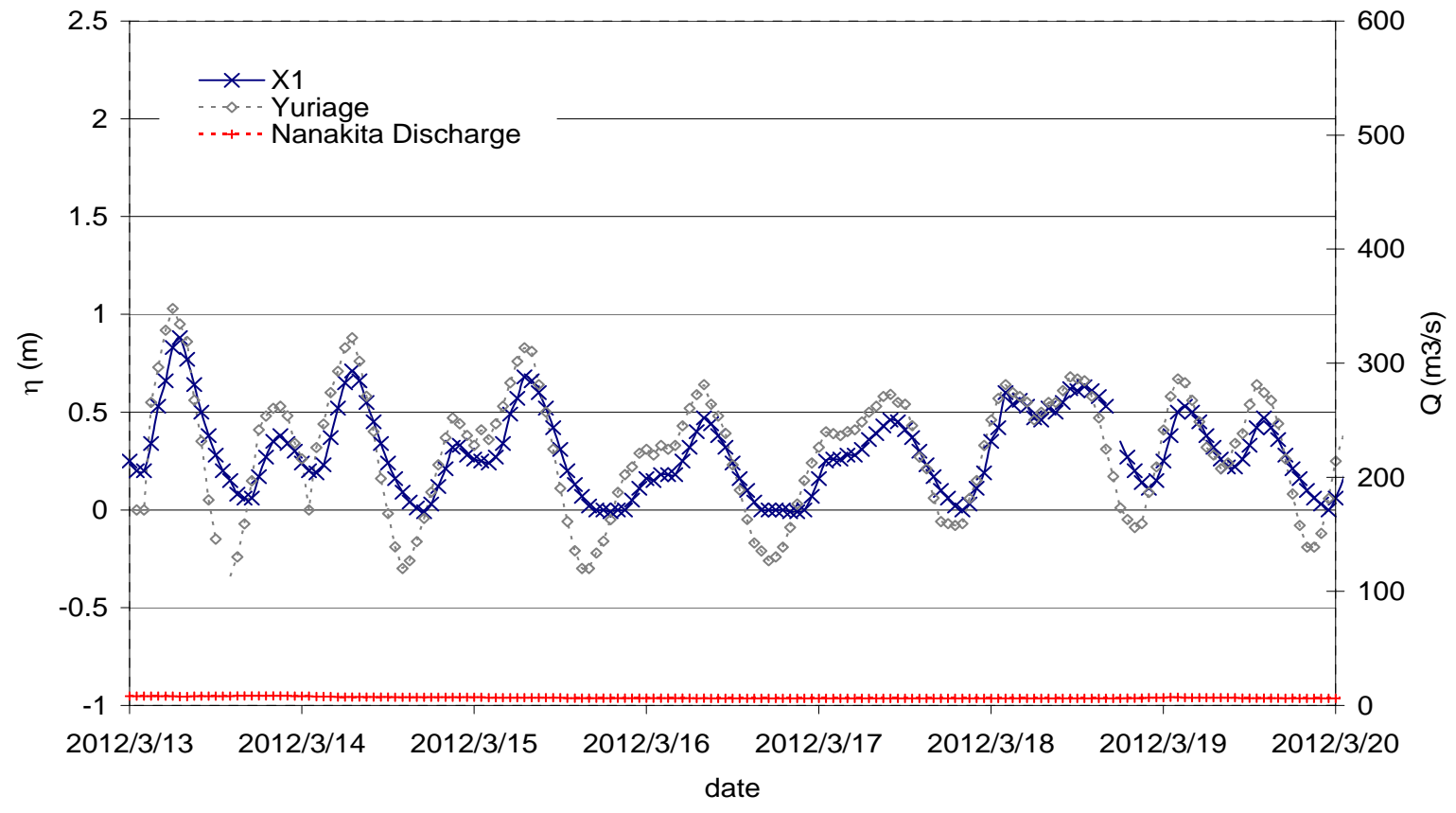

(f) 2012, 13-20 March.

Fig. 6 Temporal variation of water level. 


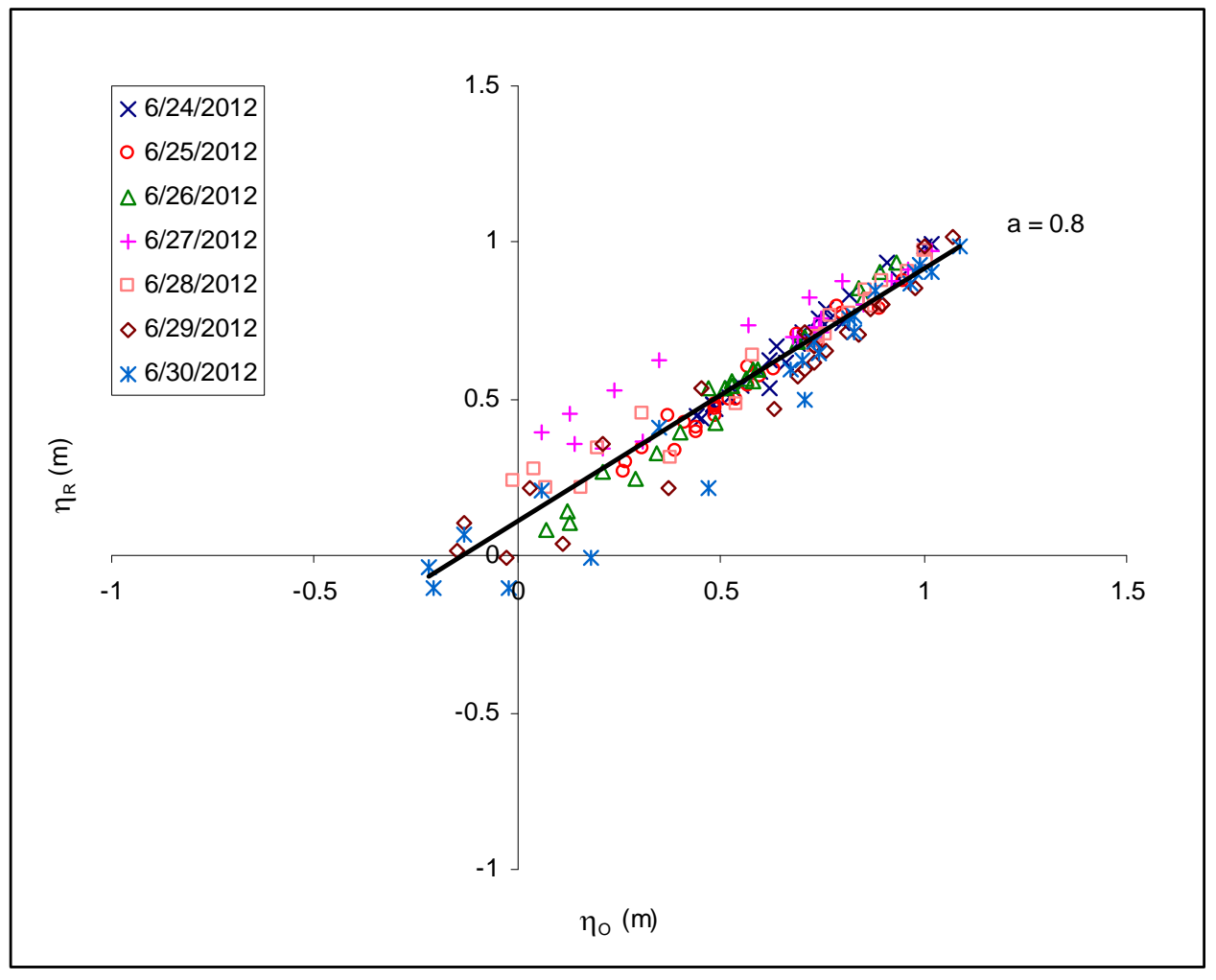

(1) 2011, 24-30 June

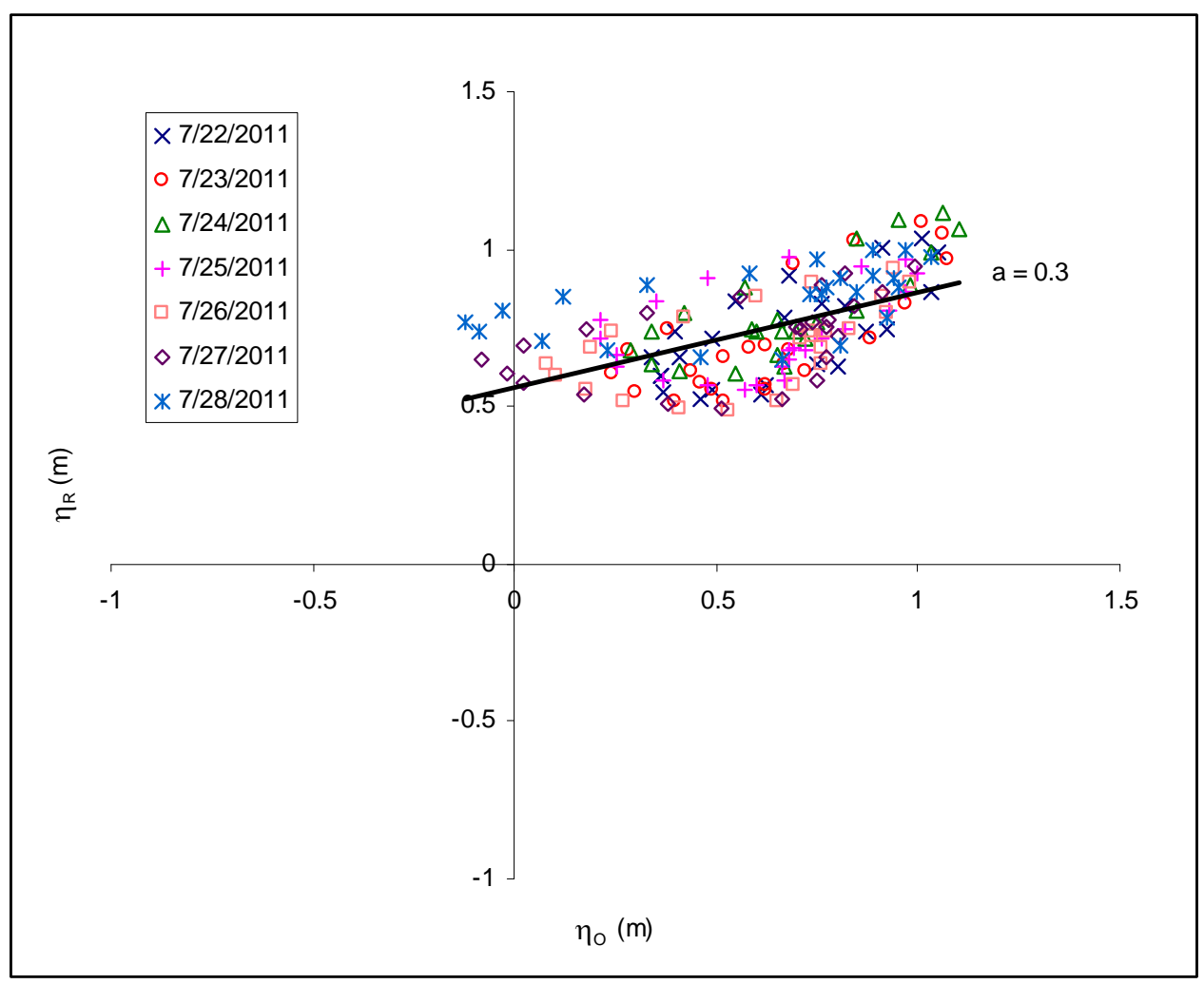

(2) 2011, 22-28 July

Fig. 7 (for caption see next page) 


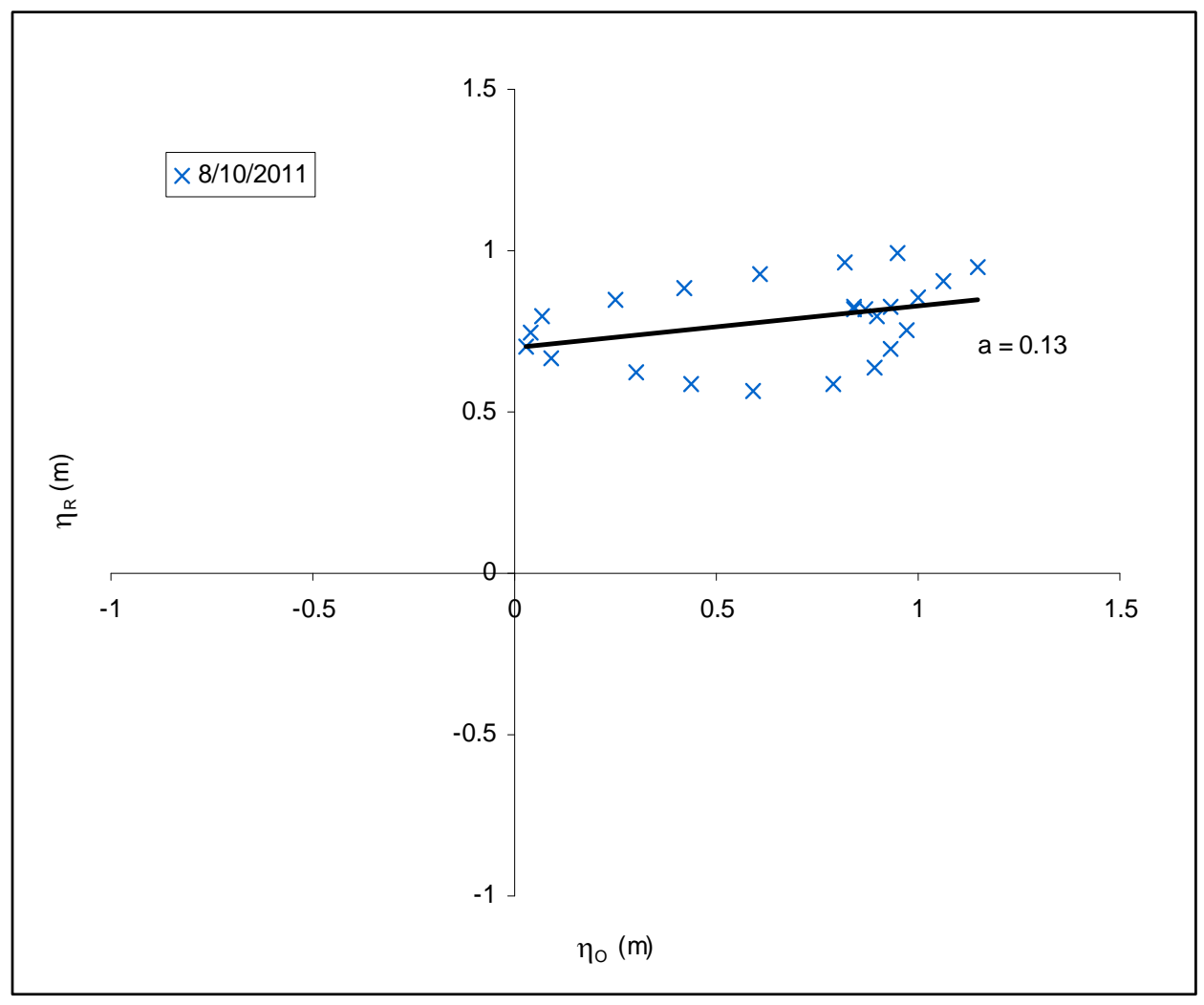

(3) 2011, 10 August

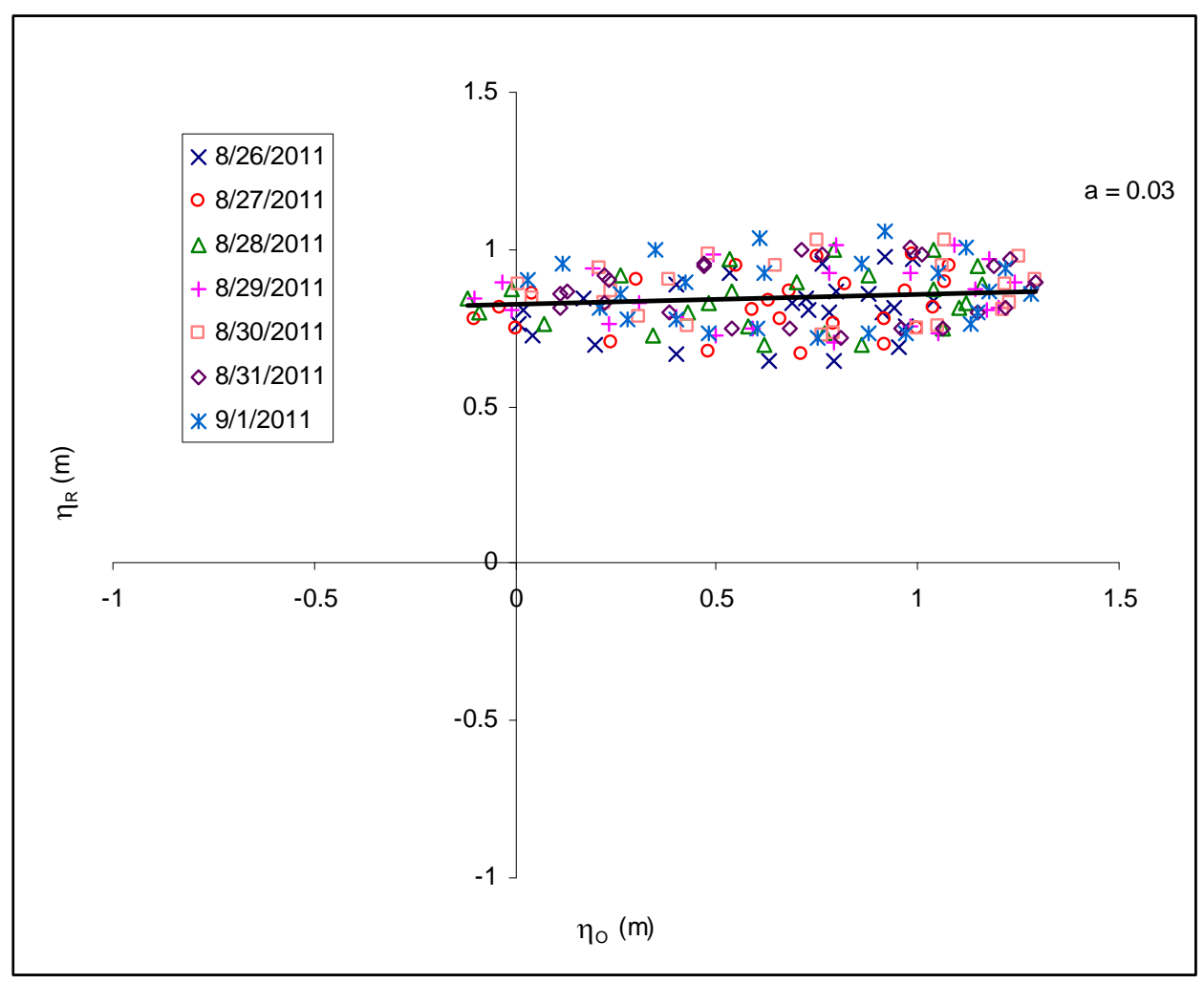

(4) 2011, 26 August-1 September

Fig. 7 (for caption see next page) 


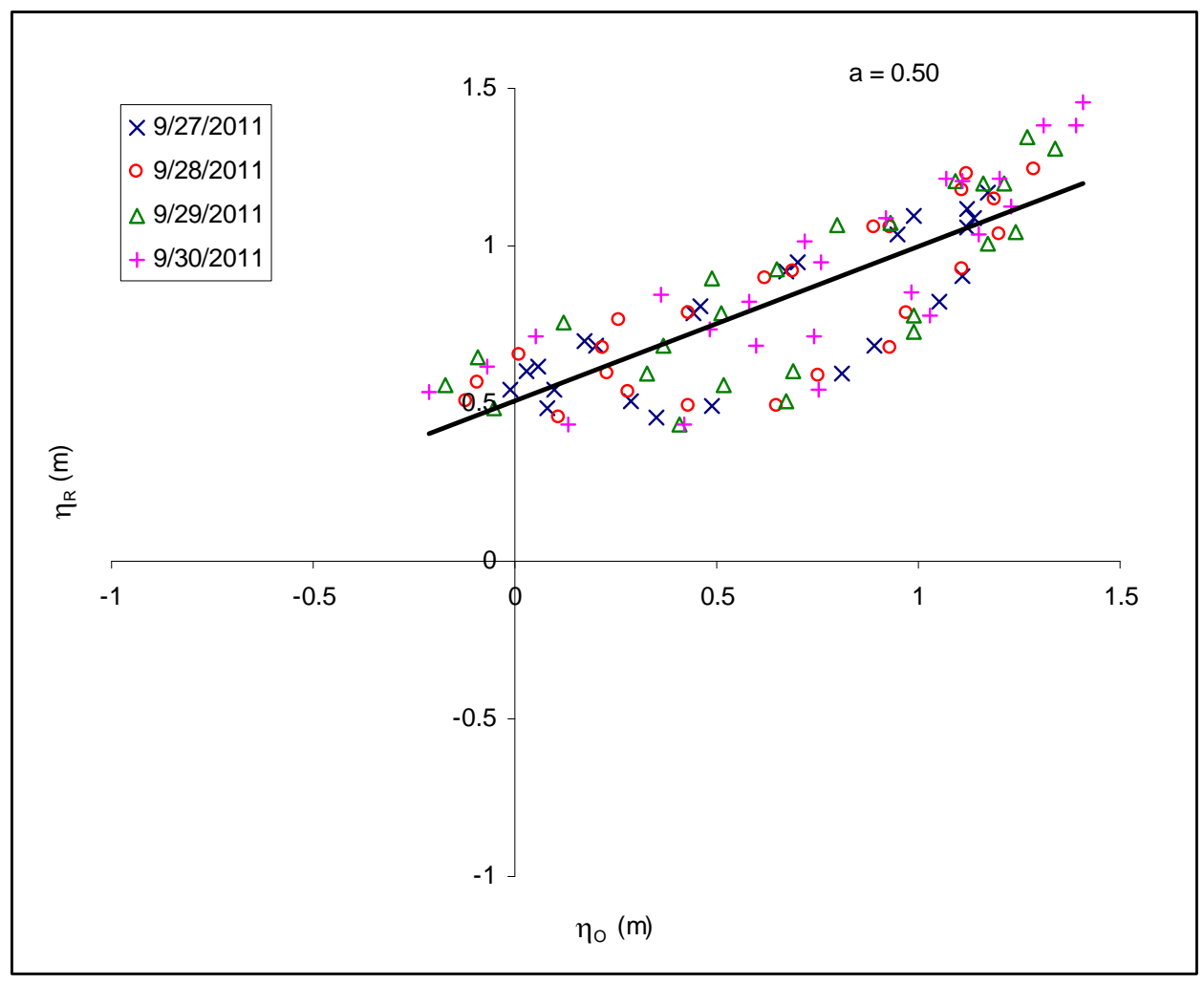

(5) 2011, 27-30 September

Fig. 7 Correlation between river mouth water level and tidal level. 


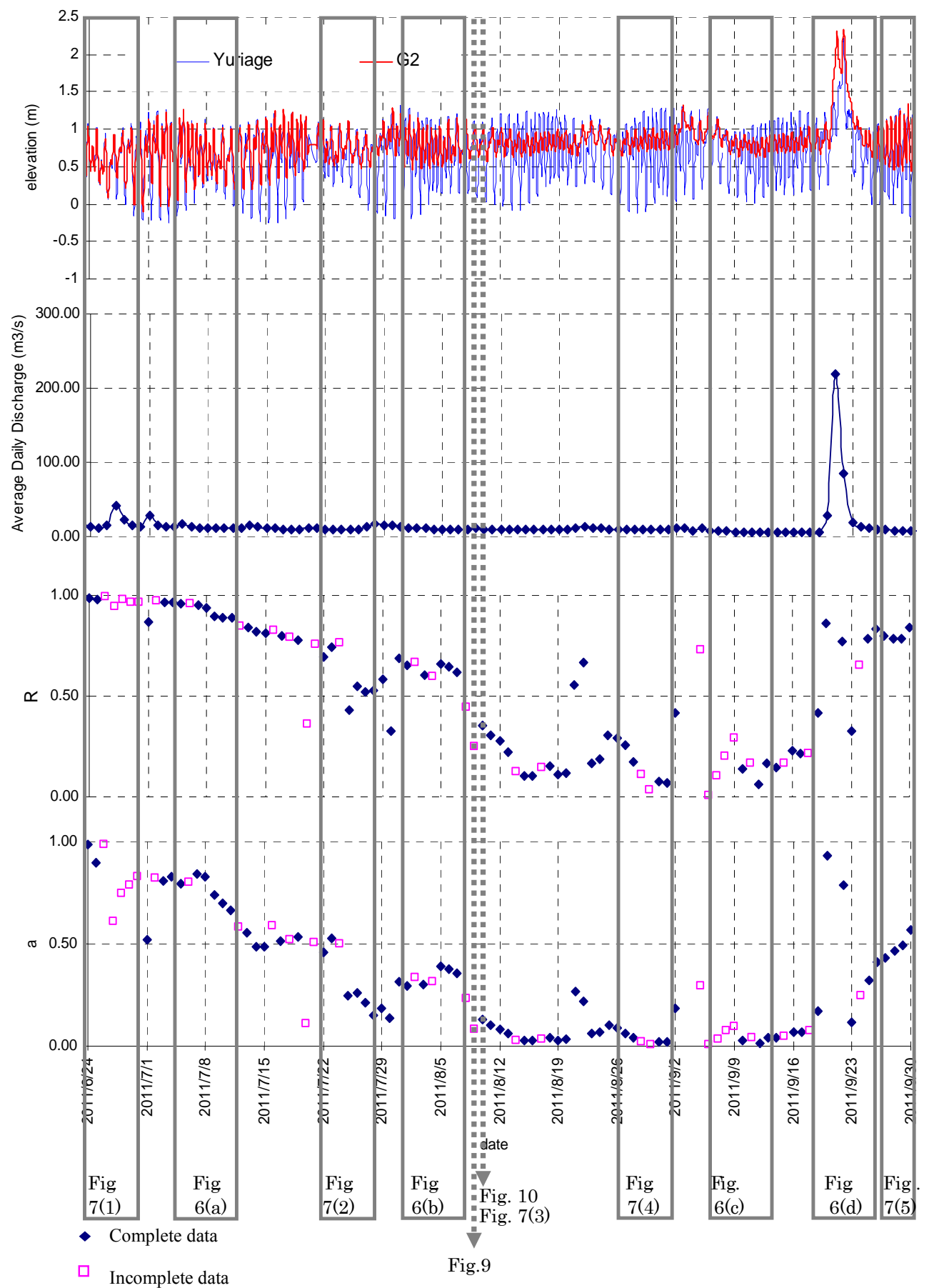

Fig. 8 Daily variation of $R$ and $a$ prior and after the river mouth blockade. 


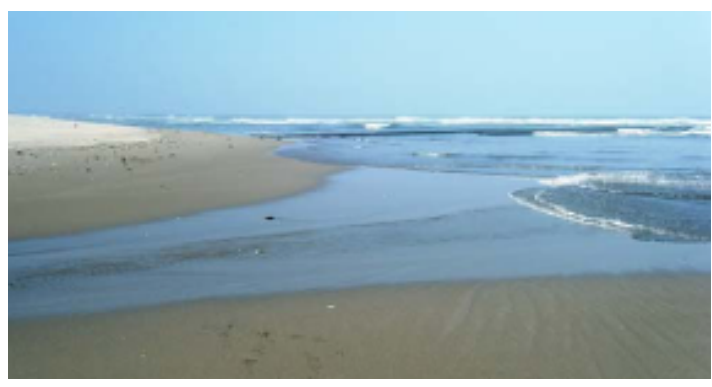

(a) View 1 (Sato, 2012)

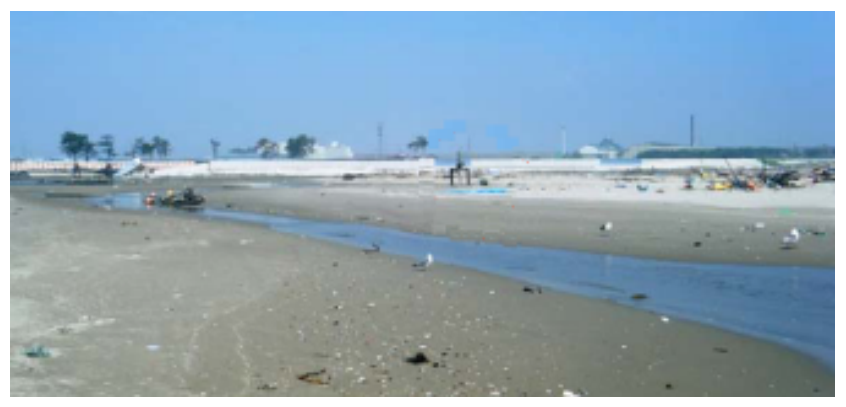

(b) View 2 (Sato, 2012)

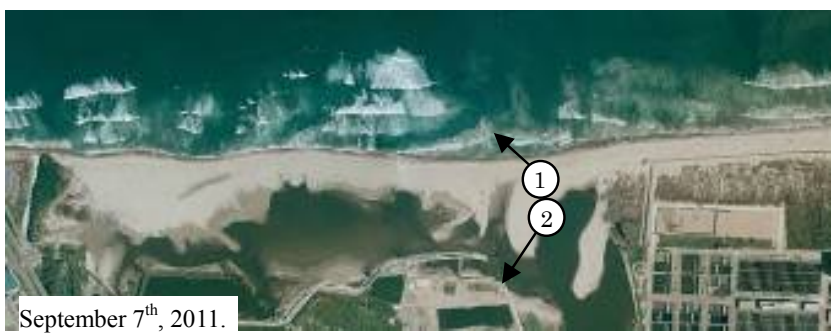

(c) View point location

Fig. 9 Photos showing the almost full river mouth blockage on August $9^{\text {th }}, 2011$

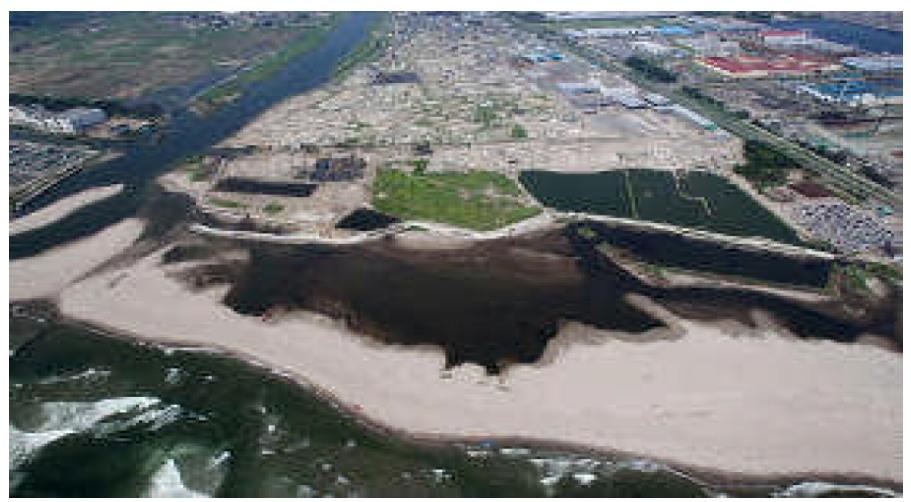

Fig. 10 Aerial-photo showing the full river mouth blockage on August 10 ${ }^{\text {th }}, 2011$ (Kahoku Shinpo, 2011) 


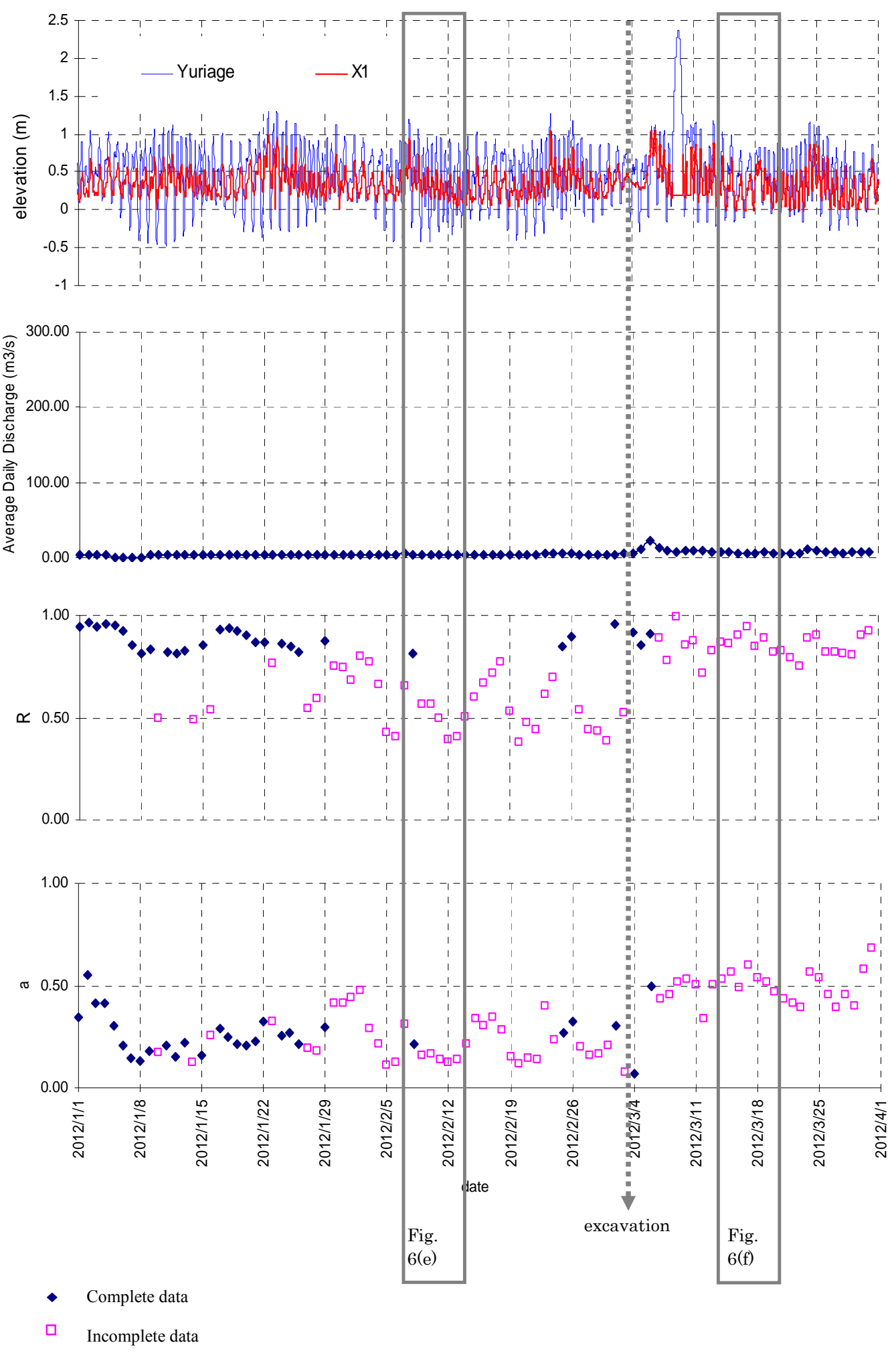

Fig. 11 Daily variation of $R$ and $a$ prior and after the excavation. 